\title{
A CSÁSZÁRKORI GERMÁN PRZEWORSK-KULTÚRA KUTATÁSÁNAK LEGÚJABB EREDMÉNYEI MAGYARORSZÁGON
}

\author{
SOÓs ESZTER*
}

\begin{abstract}
A leggyakrabban a germán vandál etnikummal azonositott Przeworsk-kultúra magyarországi településeinek kutatása az elmúlt évtizedben fontos új eredményeket hozott. A tanulmány e római császárkori kultúrkör Magyarország területén feltárt településeinek legújabb kutatási eredményeit foglalja össze, illetve ennek alapján foglakozik a településterület kiterjedésével, a relatív kronológia problémájával, az anyagi kultúra fejlődésével és a kultúra kapcsolatrendszereivel.
\end{abstract}

Kulcsszavak: Przeworsk-kultúra, vandálok, római import, kerámia, települések

The archaeological investigation of the settlements of the Przeworsk culture, generally identified with the Germanic Vandals, has yielded important new results during the past decade. The study reviews the new advances made in the study of the settlements of this Roman-period cultural complex in Hungary and addresses various issues such as the extent of the settlement territory, the problems in relative chronology, the development of material culture and the culture's connections.

Keywords: Przeworsk culture, Vandals, Roman imports, pottery, settlements

\section{Bevezetés}

A római császárkori Barbaricum hazai kutatásában az utóbbi évtizedig a germán településterület kevesebb figyelmet kapott a szarmata lelöhelyekkel szemben. ${ }^{1}$

A Kárpát-medence északkeleti határvidékének tudományos vizsgálatát számos tényező nehezíti. A Kr. u. 2-4. században kulturálisan szoros kapcsolatokat mutató terület négy ország, Szlovákia, Ukrajna, Románia és Magyarország területére esik, ezért a leletanyag egységes értelmezésének lehetőségeit máig erősen befolyásolja az egyes országok kutatási szintje és a leletanyag interpretációjának helyi hagyományai.

A hazai és a nemzetközi szakirodalom a Przeworsk-kultúra Kárpát-medencei elterjedésével sokáig csak a délkelet-lengyelországi sírokkal rokon hamvasztásos temetkezések maradványait hozta összefüggésbe. A túlnyomórészt bizonytalan kontextusból származó síranyagokat keltezé-

Kézirat beérkezett: 2019. április 12.

* Soós Eszter: 7624 Pécs, Rókus u. 2. e-mail; soos.eszter@pte.hu

1 A tanulmány megírását a Magyar Tudományos Akadémia Bolyai János Kutatói Ösztöndíja támogatta. sük alapján a Kr. u. 2. század első felében buri, ${ }^{2}$ lugi, dacringi, ${ }^{3}$ a markomann háborúkat követóen a viktofal és vandál ${ }^{4}$ csoportokkal azonosították. Az 1950-es évektől megjelent magyar publikációk a korszak kutatási módszertanának megfelelően szintén az előkerült régészeti leletanyag etnikus meghatározását helyezték előtérbe, mely kizárólag a történeti forrásokra támaszkodva torzító hatással volt annak keltezésére és értékelésére is. ${ }^{5}$

A síregyüttesekhez tartozó települések meghatározása és értelmezése sokáig problémákba ütközött a kutatásban. Az 1980-as évekig ÓzdStadion lelőhely kivételével ${ }^{6}$ nem tártak fel nagyobb felületú települést, a kutatószondákból előkerült kerámia leletanyagot annak típusai és díszítése alapján kötötték egyes etnikumokhoz. Így a kézzel formált, főként a plasztikus díszítésú, durva kerámia dák, a korongolt edények egy

\footnotetext{
BónA 1986, 63; STANCIU 1995, 172; Gindele 2013a, 19.

OLĘDZKI 1999, 109; 2017, 189-190.

4 BÓNA, 1986, 56-76; 1993, 106-107; OLĘDZKI 1992; GODŁOWSKI 1993; OLĘDZKI 1999; 2001.

5 SALAMON-TÖRÖK 1960; SALAMON 1970, 140-141; VÉGH 1964; VÉGH 1985; BÓNA 1986; VÉGH 1989.

6 PÁrducZ-KoreK 1958.
} 


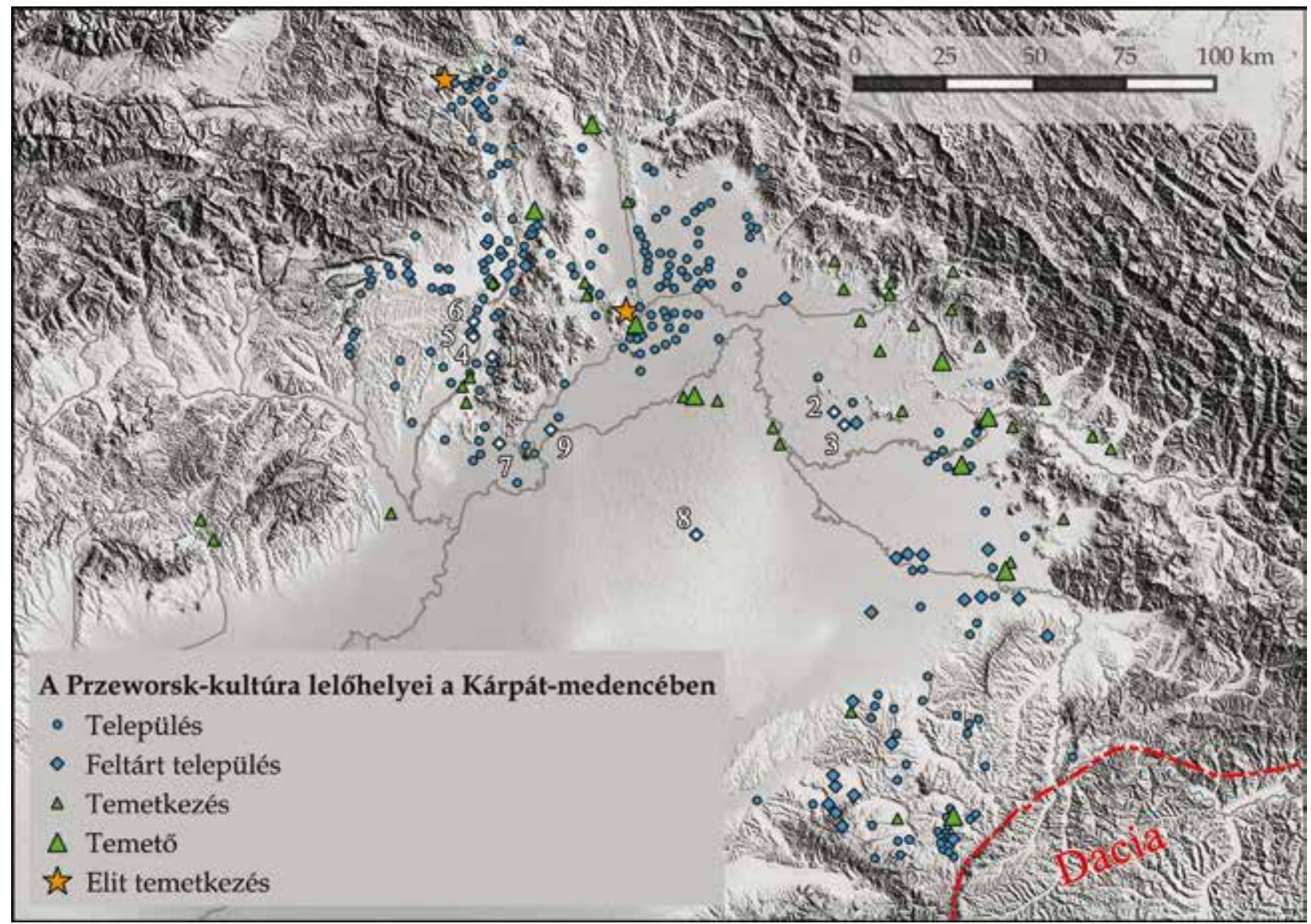

1. kép. A Przeworsk-kultúra lelóhelyei a Kárpát-medencében. 1. Arka-Fónyi-patak; 2. Beregdaróc-Zsid; 3. BeregsurányBarátságkert; 4. Garadna-Kastély-zug; 5. Garadna-Kovács-tanya; 6. Hernádvécse-Nagy-rét; 7. Mezőzombor-Temető; 8. Pócspetri-M3 201. lh.; 9. Zalkod-Jakab-domb

Fig. 1. Sites of the Przeworsk culture in the Carpathian Basin. 1. Arka-Fónyi-patak; 2. Beregdaróc-Zsid; 3. BeregsurányBarátságkert; 4. Garadna-Kastély-zug; 5. Garadna-Kovács-tanya; 6. Hernádvécse-Nagy-rét; 7. Mezőzombor-Temető; 8. Pócspetri-M3, Site 201; 9. Zalkod-Jakab-domb

része kelta, a kézzel formált, finom, fényezett áru germán azonosítást nyert annak ellenére, hogy a leletek gyakran ugyanabban a kontextusban kerültek elő. ${ }^{7}$

Salamon Ágnes topográfiai összefoglalásában az időszámításunk kezdetén az Alföld északi peremterületein és a Hernád völgyében illírek hagyatékát valószínúsítette, az Eszaki-középhegységben továbbélő kelta csoportokkal, a Borsodi-karszt északi részén púchovi emlékanyaggal számolt, miközben a vandál megtelepedés emlékeit hiányolta a kutatásból. ${ }^{8}$ Párducz Mihály a Sajó menti településeket kvádnak tar-

7 Lamiová-SChmiedlová 1969; VéGH 1964; VÉGH 1985; VÉGH 1989; VÉGH 1999

8 VÉGH 1964, 52-53; SALAMON-TÖRÖK 1960, 171; SALAMON 1966 86. A teória E. Beninger munkájára támaszkodott, aki a Púchov-kultúra hordozóit illír eredetúnek tartotta (BENINGER 1937, 99). totta, ${ }^{9}$ ugyanott Kemenczeiné Végh Katalin később a vandál csoportok térfoglalásával számolt. ${ }^{10} \mathrm{Az}$ etnikus értelmezés fényében a területen a kora császárkorban dák, kelta, germán elemekból álló, kevert népességet (Mixed Culture) azonosítottak, a településeken előkerült, különböző technológiával készült kerámiatípusokat közvetlenül etnikai csoportoknak feleltetve meg. ${ }^{11}$

A késő császárkorban a fazekasmúhelyekben gyártott, gyorskorongolt, jó minőségú kerámia egyre nagyobb arányban volt használatban a településeken. A vaskori vagy római eredetú technológián ${ }^{12}$ alapuló fazekasságot nem lehetett egy

\footnotetext{
9 Miskolc-Feketekapu (PÁRduCZ 1957); Ózd-Stadion (PÁRdUCZKOREK 1958)

10 Sajókeresztúr (VÉGH 1985, 106); Szirmabesenyő (VÉGH 1999, 219).

11 LAMIOVÁ-SCHMIEDLOVÁ 1969, 458-466; OlEEZZKI 2014.

12 GINDELE 2015a.
} 
konkrét népcsoporthoz kapcsolni, így a kutatás etnikailag nem meghatározható csoportokkal számolt, lezárva a Przeworsk-lelőhelyek keltezését a Kr. u. 2-3. század fordulóján vagy a 3. század első évtizedeiben. ${ }^{13}$ Ugyanezen módszertani megközelítés alapján terjedt el a „Bereg-kultúra” fogalma, mely a késő császárkori, szürke, bepecsételt mintákkal díszített, korongolt edényeket és azok lelóhelyeit jelöli. ${ }^{14}$

Napjainkra a Przeworsk-kultúra településhálózata és a telepekre jellemzó anyagi kultúra is egyre pontosabban körvonalazható. ${ }^{15}$ A magyarországi kutatás számára kiemelkedő lehetőséget teremtenek az ezredforduló körül a BorsodAbaúj-Zemplén megyében is meginduló, nagy felületú leletmentő feltárások eredményei. Elsósorban a Miskolcot Kassával összekötő, a Hernád jobb partián futó, 3-as számú főút bővítési és rekonstrukciós munkái során feltárt lelőhelyek, mint Garadna-Kovács-tanya és HernádvécseNagy-rét jól dokumentált jelenségei és selejtezetlen leletanyaga szolgáltatnak alapot a modern feldolgozások számára. ${ }^{16} \mathrm{Az}$ eredmények lehetőséget adtak a korábban, kis felületen kutatott vagy csak rétegadatokkal dokumentált telepanyagok elemzésére és újraértékelésére is, mint Arka-Fónyi-patak, ${ }^{17}$ a Taktaközből MezőzomborTemető, ${ }^{18}$ a Bodrogköz területén Zalkod-Jakabdomb, ${ }^{19}$ valamint a nemrégiben feltárt lelóhelyekkel való összevetésre is, mint BeregdarócZsid és Beregsurány-Barátságkert. ${ }^{20} \mathrm{~A}$ történeti források alapján kialakított topográfia helyett a kultúrkör elterjedése is a leletanyag alapján lesz igazolható.

\section{Földrajzi keretek}

A Przeworsk-kultúrkör Kárpát-medencén belüli területe a Felső-Tisza vidék északkeleti, dombvidéki területeit foglalja magába, nagyjából a Tisza vonalától a Kárpátok hegylábi folyóvölgyeiig (1. kép). ${ }^{21} \mathrm{Az}$ eddig ismert adataink arra utalnak, hogy délkeleti irányban a daciai limes, dél-délnyugat felé pedig az alföldi szarmata településte-

13 Lamiová-Schmiedlová 1969; Lamiová-Schmiedlová 1992; PINTYE 2010.

14 Részletesen: Soós in press.

15 Gindele-IsTVÁNOVITS 2009; Gindele 2010.

16 A tanulmányban említett publikálatlan lelőhelyeket a szerző dolgozta fel doktori disszertáció keretében (Soós 2015).

17 Soós 2017

18 CSENGeri 2015

19 SALAMON 1970.

20 Pintye 2010; IstVÁnOVITS 1997.

21 Gindele 2010, 9-11; LAMIOVÁ-SchmiedLová 1969, Abb. 1; Soós 2016, Fig. 1. rület felé éles határvonal fogható meg kiterjedésében. ${ }^{22}$ Nyugati határa a kevés publikált új ásatás miatt kevésbé tisztázható, de a Sajótól nyugatra inkább a kvád anyagi kultúra jellemzói domináltak. ${ }^{23}$ A Miskolc környékén feltárt települések leletanyaga kvád és Przeworsk-jellemzőket is hordoz, lehetséges, hogy a két germán kultúrkör viszonylag széles átmeneti zónájával számolhatunk. ${ }^{24}$ Északkeleti határa a legkevésbé ismert: egyelőre vitatott, hogy a Kárpátokon belül feltárt halmos temetkezések a kárpáti halomsíros kultúra (Carpathian Barrow Culture) köréhez sorolhatóak, vagy csupán a halom állításának szokása jelent meg bizonyos Przeworsk-lelőhelyeken. ${ }^{25}$

Magyarország területén a Hernád-völgy, a Szerencsköz, a Bodrogköz és a Beregi-Tiszahát területe biztosan a kultúrkörhöz tartozott.

\section{Garadna-Kovács-tanya (Elkerülő út, 1. 1h.)}

A Hernád völgyében, a Bársonyos patak teraszán húzódó, Garadna-Kovács-tanyai teleprészlet jelenleg Csengersima-Petea után ${ }^{26}$ a második legnagyobb felületen dokumentált és feldolgozott Przeworsk-település a Kárpát-medencében.

A $6100 \mathrm{~m}^{2}$ kiterjedésú feltárt felületen, 20022003 során 434 római kori régészeti jelenség került napvilágra. ${ }^{27}$ A nagyjából 160 m-es tszf-i magasságon húzódó keskeny folyóteraszon a jelenségek az egykori Bársonyos-patak partját követve, csoportokban helyezkedtek el. Minden, egymástól 20-35 m-re elhelyezkedó jelenségcsoportot földbe mélyített, cölöpszerkezetes épületek, nagyobb alapterületú, szabálytalan formájú, hulladékkal feltöltött agyagnyerő gödrök, tárolóvermek és -gödrök, valamint kiégett oldalú, négyszögletes tüzelőhelyek alkottak (2. kép).

A legészakabbi csoportot egy kisebb alapterületú, kétoszlopos, oldalai mentén több cölöplyukkal ellátott és legalább három hatoszlopos építmény alkotta. Környezetükben több, részben bizonytalan stratigráfiai helyzetú, nagyméretú gödörkomplexumot tártak fel. A második jelenségcsoporthoz legalább 9-10 épület tartozott, melyek közül nyolc két párhuzamos, $\mathrm{Ny}-\mathrm{DNy}-$ K-ÉK irányú sorban helyezkedett el. A feltárt felület északi és középső részén koncentrálódott a

\footnotetext{
22 GINDELE 2010, 10, Karte 2; MASEK 2012, 254-256.

23 Soós 2017, 36-37; Soós-TANKó 2018a, 295-296, Fig. 1-2.

24 A pontosabb kép megrajzolásához a Sajó-völgyi települések újbóli vizsgálata szükséges (VÉGH 1989; VÉGH 1999).

25 KobÁly 1998, 122-123; VAKULENKO 2008, 141-142, 148, 165, Fig. 1; IstVÁNOVITS-Kulcsár 2017, 255-256, Fig. 204.

26 Gindele-ISTVÁNOVITS 2009; GINDELE-ISTVÁNOVITS 2011.

27 A feltárásról részletesen: CSENGERI-PUSZTAI 2008, 97.
} 


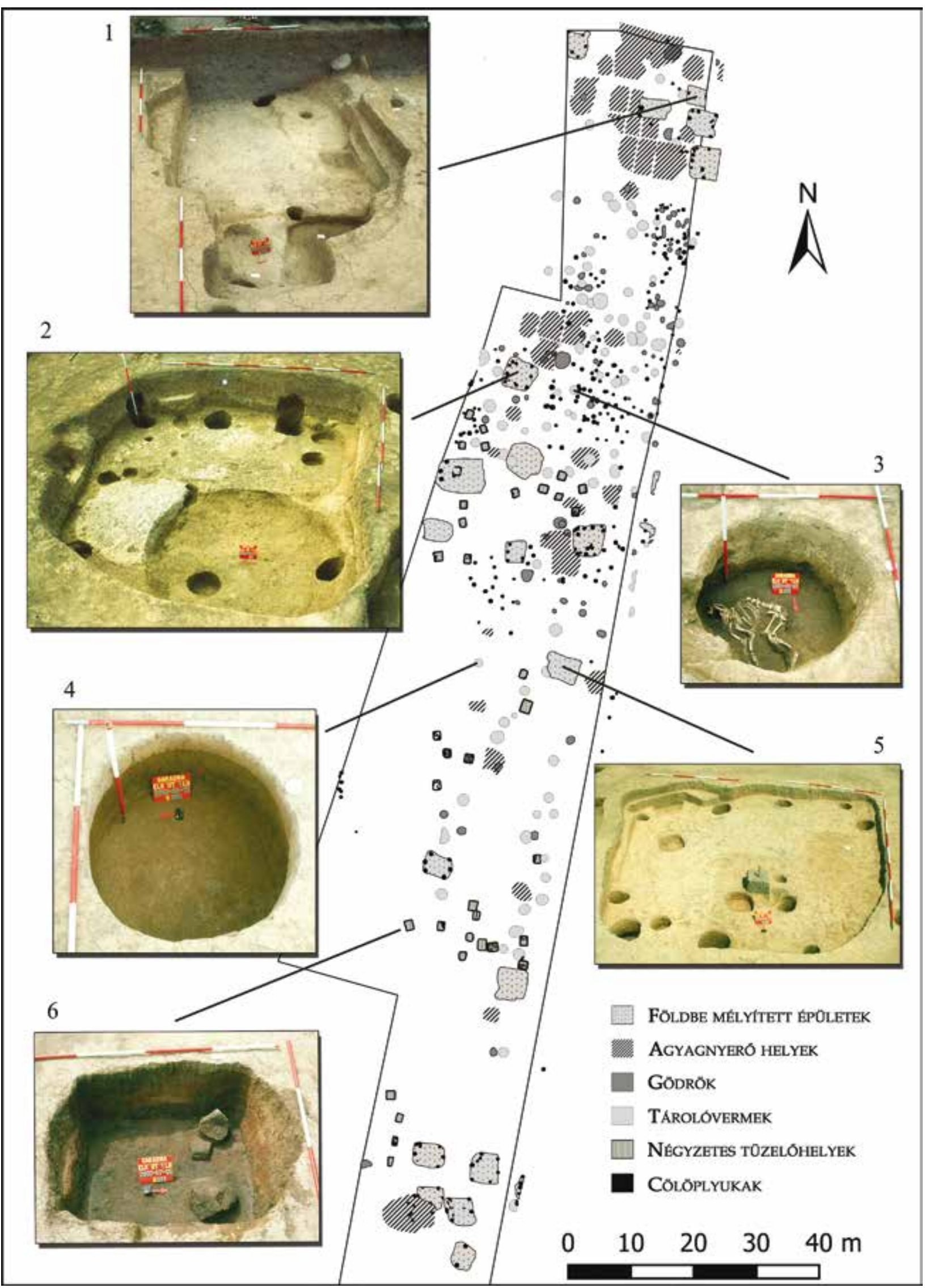

2. kép. Garadna-Kovács-tanya. 1. s108; 2. s9; 3. s255; 4. s230; 5. s302; 6. s331 Fig. 2. Garadna-Kovács-tanya. 1. s108; 2. s9; 3. s255; 4. s230; 5. s302; 6. s331 
134 méhkas alakú vagy hengeres tárolóverem és -gödör legnagyobb része, melyek elhelyezkedésében szabályosságot vagy csoportosulást nem lehetett megfigyelni (2. kép 4). Szintén a második jelenségcsoport környezetében jelentkeztek először az átégett oldalú, négyszögletes tüzelőhelyek, melyek leletanyagot nem, csak szenült famaradványokat és nagyobb köveket tartalmaztak. A harmadik, az előzőtől 20 m-re, délre feltárt objektumcsoport egy épületból és egy agyagnyerő gödörből állt. A negyedikhez is csupán két épület sorolható, szintén gödrökkel, tüzelőhelyekkel kiegészülve. Az utolsó csoportot a felszín déli sarkában hét, egymáshoz igen közel leásott, részben egymást metsző épület és több tüzelőhely alkotta, néhány tárolóveremmel együtt.

A lelőhely északi felében előkerült cölöplyukak egy része valószínúleg kisebb alapterületú, felszíni építmény nyoma lehetett, azonban összetartozásuk megfigyelhető járószint hiányában, valamint a számos szuperpozíció miatt bizonytalan. A háztartási hulladékon kívül 22 gödörből részleges vagy teljes állatvázak kerültek elő, nagyrészt kutyák, de sertések, kiskérődzők és macskák maradványai is megfigyelhetóek voltak (2. kép 3). ${ }^{28}$

A régészeti jelenségek egy része, mint a gödrök, cölöpszerkezetek, a méhkas alakú vermek általánosan jellemzőek a római császárkori, barbaricumi településekre. Megfigyelhetőek azonban olyan jellegzetes objektumok, mint a négyzetes alakú tüzelőhelyek vagy bizonyos épülettípusok, melyeknek számos analógiája található római kori germán területen.

A kisebb alapterületú, rövidebbik oldalainak közepén egy-egy oszloppal ellátott épület (2. kép 1) a Droberjar-féle A1/Kolník II/Behm-Blancke 2/Leube A típusba sorolható. ${ }^{29}$ A Kárpát-medencei germán telepeken ezek a kisméretú épületek általában nem önmagukban jelennek meg, hanem egyéb földbe mélyített és földfelszíni építmények társaságában. A kétoszlopos típus analógiái Nyugat-Szlovákiából kimondottan a késő La Tène-időszakból és a kora császárkorból ismertek, így a publikációk a késő vaskori hagyomány továbbéléseként tekintenek a jelenségre. ${ }^{30}$

A garadnai hatoszlopos épületeknél a legtöbb esetben a cölöplyukak a rövidebb oldal mentén sorakoztak (2. kép 5), ami a Kolník 4/2/Leube

28 DARÓcZI-SZABÓ 2009; SoÓs 2015, 218-224.

29 Leube 2009, Abb 99; újabb tipológia alapján Kolník 2/1 (KolNíK 1998, 145, Abb. 1).

30 KolníK 1962, 368; Droberjar 1997, 19; KolníK 1998, 146; VARSIK 1999, 629-630, Abb. 5. Branč-Helyföldek kvád lelőhelyen a telep korai időszakában szintén használatban volt az épülettípus (KoLNíK et. al. 2007, 13-19, Obr. 7).
C2/Donat C1 szerkezettípusnak felel meg. ${ }^{31}$ A Kárpát-medencén belül ez a konstrukció föként Észak-Erdély, Partium és Kárpátalja területén volt gyakori. ${ }^{32}$ A típus szoros összefüggést mutat a rövidebb oldal mentén négy cölöphellyel rendelkező épületekkel, a két szerkezettípus nem választható szigorúan külön egymástól. ${ }^{33}$

Garadnán három esetben az építmények hossztengelyében levő cölöplyukakon kívüli oszlopokat nem a sarkokba, hanem a hosszabb oldalak mentén ásták le (2. kép 2). A szerkezet, ami eddigi adataink alapján Kárpát-medencei jellegzetesség, a Droberjar-féle B1/Kolník 3/1/Leube C1 típusként került meghatározásra. ${ }^{34} \mathrm{Az}$ épülettípus a Kárpát-medencei Przeworsk-kultúrkör kvád területekkel szomszédos vidékén, a Hernád-völgyben és attól nyugatra volt inkább használatban. A Kr. u. 2. század második felétól terjedtek el Przeworsk-területen, és a késő császárkorban is használatban maradtak. ${ }^{35}$

A jelenségek közül figyelmet érdemelnek a négyszögletes, kis alapterületú, átégett oldalú tüzelőhelyek, melyek Garadnán nagyjából É-D és $\mathrm{K}-\mathrm{Ny}$ irányú sorokba rendezve, tízes, húszas csoportokban kerültek elő (2. kép 6). A jelenségek az eddigi kutatások alapján szinte kizárólag a Przeworsk-kultúra településeire jellemzőek, mind a kultúrkör lengyelországi törzsterületén, mind a Kárpátokon belül. Funkciójukat mind ez idáig nem lehetett pontosan meghatározni, településeken belüli elhelyezkedésük és számuk alapján valamilyen ismétlődő háztartási tevékenység nyomai lehetnek. ${ }^{36}$

Garadna-Kovács-tanya lelóhely a kiterjedt felületen dokumentált telepszerkezet és a számos jelenségtípus mellett a nagy mennyiségü, kontextusból előkerült leletanyag alapján is kiindulópontot jelent a kutatás számára. A leletanyag nagy része a háztartási hulladékként tízezres nagyságrendben előkerült kerámia- és állatcsonttöredék volt. A kerámia leletanyag a kézzel formált, fényezett, feketére égetett, jellegzetes Przeworsk-edényeken kívül nagy mennyiségü,

31 Kolník 1998, 145, Abb. 1; Leube 2009, 133, Abb. 99.

32 Typ. 3: Gindele-IstVÁNOVITS 2009, 13-14, Abb.1; KotigorosKo 1995, Fig. 75.

33 Ahogy Csengersimán is, utóbbi a 4-es típus. Legnagyobb számban a 2a fázisra keltezhetőek, de a császárkor végéig megfigyelhető használatuk (GINDELE-ISTVÁNOVITS 2009, 14, Abb. 1).

34 Droberjar 1997, 22; Leube 2009, 147; Kolník 1962, 396-397; KolNíK 1998, 145, Abb. 1, ott a 3/1. típus.

35 PÁrducz-KoreK 1958, 25, 95. jelenség, 3. kép 3; LAMIOVÁSCHMIEDLOVÁ 1969, 418, Abb 3/2, Abb 8; Soós 2017, 20.

36 A korai kutatásban szénégető boksának, füstölőnek és ércpörkölőnek meghatározott jelenségeket újabban Gindele Róbert rituális tevékenységgel hozta összefüggésbe (Soós 2011; GINDELE 2015b). 


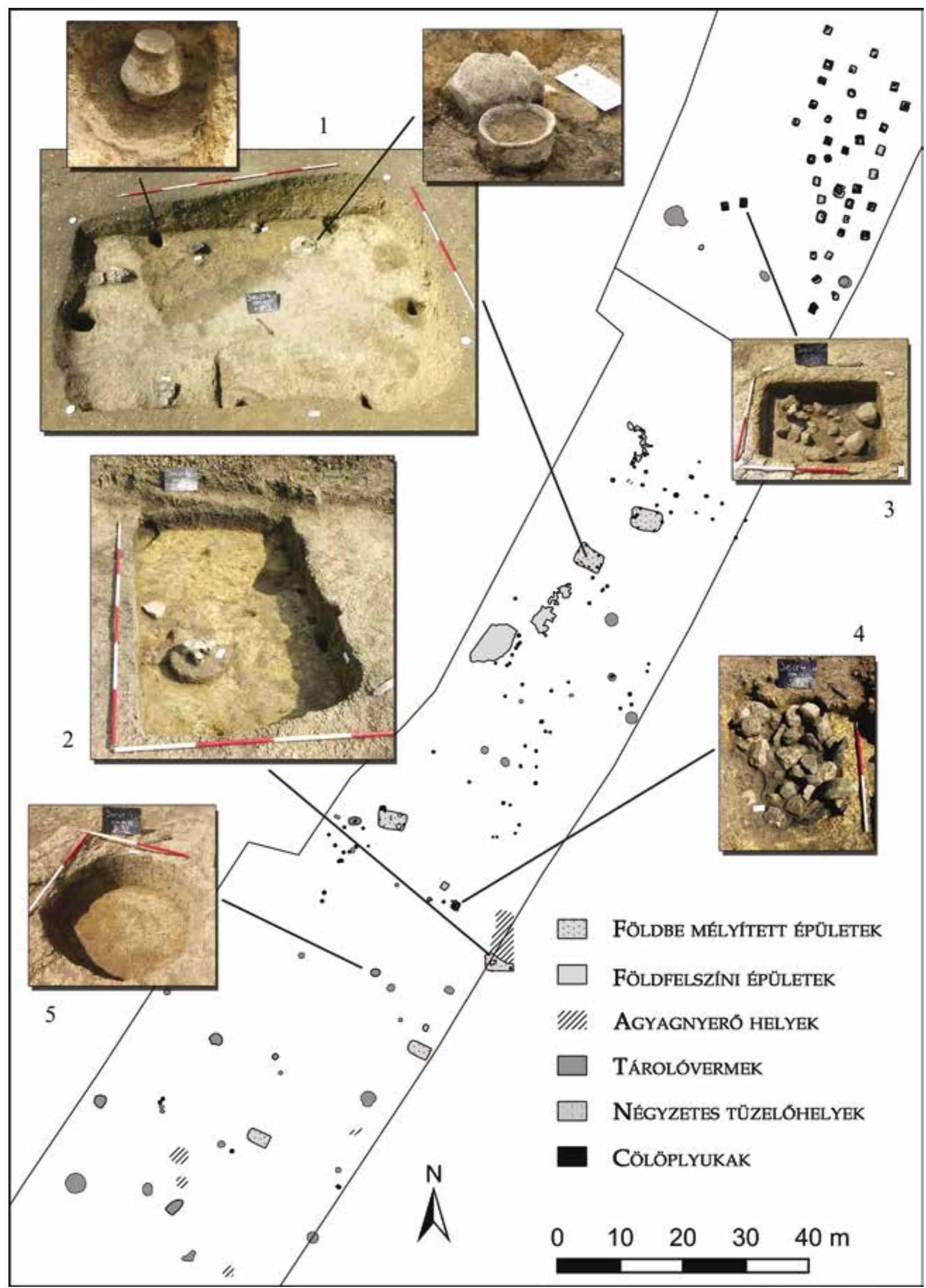

3. kép. Hernádvécse-Nagy-rét, 4-5. lelőhelyek. 1. s183; 2. s114-115; 3. 5. 1h/s10; 4. s140; 5. s32 Fig. 3. Hernádvécse-Nagy-rét, Sites 4-5. 1. s183; 2. s114-115; 3. Site 5; 4. s140; 5 . s32 
változatos formavilágú és funkciójú durva főzőedényt is tartalmazott. A lelőhely korai fázisától kezdve számolhatunk gyorskorongolt kerámia használatával is, tárolás céljára pedig nagyméretû, vastag falú hombárok szolgáltak.

A római provinciális területekkel való kapcsolatra a csaknem $70 \mathrm{db}$, a rheinzaberni, westerndorfi és pfaffenhofeni múhelyekben készült terra sigillata töredék mellett ${ }^{37}$ pannóniai agyagbevonatos áru (Pannonische Glanztonwäre) 47 töredéke és három, barbár területen ritka üvegpohár maradványa is utal. A helyi kerámiaanyagban elöforduló formai megoldások és bizonyos díszítéstípusok alapján a szarmata és a kvád anyagi kultúra hatása is megfigyelhetó.

Az étkezési hulladékként előkerült állatcsontmaradványok nagy része szarvasmarha volt. A letelepült életmódra utal, hogy második helyen a fogyasztott fajok sorában a sertés állt a kiskérődzők előtt, valamint hogy vadállatok maradványai kevesebb mint $1 \%$-ban voltak jelen a leletanyagban. ${ }^{38}$

A lelőhely a telepjelenségek típusai, egymáshoz való viszonya és a szuperpozíciók, valamint a leletanyag alapján hosszú ideig, megszakítás nélkül volt lakott. Kezdeti fázisa a B2/C1 periódusra tehető, és megérte a C3/D1 időszakot is, így a Kr. u. 2. század második felétől a 4. század utolsó harmadáig követhető az élet a lelőhelyen.

\section{Hernádvécse-Nagy-rét, 4-7. lh.}

A Garadna-Kovács tanyától mintegy 6 km-re, északra elhelyezkedő Hernádvécse-Nagy-rét, 4, 5, 6, 7. számú lelőhelyeken 2004-ben végeztek leletmentő feltárást a Miskolci Herman Ottó Múzeum munkatársai. A Hernád keskeny teraszán húzódó lelőhelyeken neolitikus, késő bronzkori telepjelenségek is előkerültek, valamint egy hun kori tanya is napvilágot látott. ${ }^{39}$

A Przeworsk-település jelenségei a 4-5. és a 6-7. lelőhelyek területén, egymástól nagyobb távolságra jelentkeztek, sûrúsödésük alapján két tanyaszerú telep nyomaként határozhatóak meg (3. kép).

A 4. lelőhely északi felében egy települési egység központi részét három egymástól 10-20 m-re elhelyezkedő, földbe mélyített, hatoszlopos szerkezetú épület és három, bizonytalanul meghatározható, felszíni cölöpszerkezetes építmény alkotta (3. kép 1). A háztartási hulladék nagy része - hasonlóan Garadna-Kovács-tanyához - kisebb

\footnotetext{
37 GYalai 2009.

38 DARÓCZI-SZABÓ 2009.

39 Utóbbi részletes közlése: Soós et al. 2017.
}

és nagyobb, szabálytalan alakú gödörkomplexumokból származott, melyeket az előbbi épületektől mintegy $40 \mathrm{~m}$-re, északra és délre tártak fel. A 4. lelőhely déli felében három kisebb alapterületú, egy- vagy kétoszlopos, földbe mélyített épület állt, környezetükben hengeres és méhkas alakú tárolóvermek voltak (3. kép 2, 5). Hernádvécsén a négyzetes tüzelőhelyek a felszíni épületektől 40-50 m-re északra, sorokba rendezve jelentkeztek (3. kép 3-4). Az 5. lelőhely déli felében és a 7. lelőhelyen előkerült több tucat tüzelőhely önálló településrészt alkotott, közelükben más jelenség nem került elő. ${ }^{40}$

Hernádvécse kisebb alapterületú és hatoszlopos, földbe mélyített épületei számos analógiával rendelkeznek a Zempléntől nyugatra fekvő, Kr. u. 2-3. századi lelőhelyekkel. ${ }^{41}$

A település kerámia leletanyaga szinte kizárólag kézzel formált edényekből állt. A finom, fényezett, feketére égetett Przeworsk-tálakat, -tálkákat és -fazekakat változatos formájú és funkciójú durva edények, fazekak, tálak, csészék, fedők, miniatúr edények és sütótálak egészítették ki. A gyorskorongolt technológiát csak pár nagyméretú hombár töredéke képviselte. A település archaikus jellegú kerámiaanyagát római import darabok, rheinzaberni és westerndorfi sigillata töredékek, egy korai mortárium és egy zöld, hasábos testú üvegpalack töredéke egészíti ki.

Hernádvécse-Nagy-rét települése szintén a B2/C1 periódusban, a Kr. u. 2. század második felében létesülhetett, felsó időhatára a 3. századon belül nem határozható meg pontosabban.

Annak ellenére, hogy időbeli átfedés tapasztalható Garadna-Kovács-tanyával, a két település leletanyaga eltérő hagyományokról és részben eltérő szokásokról tanúskodik. Hernádvécse az archaikus kerámiaformák, a gyorskorongolt edények szinte teljes hiánya, valamint a szórt, tanyaszerú településszerkezet alapján egy, a markomann háborúk időszakában újonnan a FelsőTisza-vidékre beköltöző csoport hagyatékaként határozható meg. ${ }^{42}$

\section{A magyarországi Przeworsk-települések időrendje}

\section{A Kr. u. 1. századi leletanyag problémája}

A Przeworsk-kultúrkör Kárpát-medencén belüli térhódítása a Kr. u. 2. század első felétől, vagy

40 A négyszögletes tüzelőhelyek telepen belüli elkülönülése több esetben is megfigyelhető volt (GINDELE 2015b, 91-93).

41 Lásd 34. jegyzet.

42 Több, elsősorban romániai lelőhely alapján (GINDELE 2014, 141). 
legkorábban az 1-2. század fordulójától, a B2 fázistól datálható. ${ }^{43}$

A Kr. u. 1. századi emlékanyag leválasztása és meghatározása problémás, az alföldi szarmata területekhez hasonlóan ${ }^{44}$ a Felső-Tisza-vidéken is. A szakirodalom egy része a kelta és dák jellegú emlékanyag kora császárkori, általános továbbélésével és germán elemekkel való keveredésével számol, ${ }^{45}$ mely azonban igen kevés esetben bizonyítható.

A Kárpát-medence északkeleti részén csak egyes, központi szerepet betöltő lelóhelyek keltezhetóek biztosan a La Tène D idószakra. ${ }^{46}$ A szlovák kutatásban definiált kelto-dák horizont Kr. e. 1. század és a Kr. u. 1. század közé datálható, besimított díszú és vörös, festett, ill. egyértelmúen dák jellegú kerámiaanyaga erődített központi telepekhez és azok közvetlen környezetéhez köthető, mint Zemplén-Várhegy ${ }^{47}$ vagy Mala Kopanya. ${ }^{48} \mathrm{~A}$ tágabb régióban a síktelepülések kerámiaformái megfeleltethetőek a La Tène B2/ C1 telepek leletanyagának, így közvetlenül nem bizonyítható, hogy későbbre keltezhetőek, mint a Kr. e. 3-2. század. ${ }^{49}$

Több magyarországi és szlovákiai, kora császárkortól vagy a Kr. u. 1. századtól indított település keltezése azon alapult, hogy a leletek között kelta töredékek fordultak elö, melyeket vagy a telep korai rétegeként határoztak meg, vagy a leletanyaghoz soroltak..$^{50}$

Részletesen vizsgálva az említett publikációkat azonban megállapítható, hogy a La Lène jellegú leletanyag császárkori keltezése kérdéses. A Sajó-völgyi és Miskolc környéki településeken, mint Sajókeresztúron vagy Miskolc-Szirmán a korongolt S-profilú tálak és fazekak töredékei legtöbbször szórványként vagy csupán mélységadattal dokumentálva szerepelnek, így a római korhoz való sorolásuk vitatható. ${ }^{51}$ Meg kell említeni azonban, hogy a felbukkanó kelta jellegú

43 A római császárkori régészeti anyag keltezése provinciális import tárgyakon és kerámia formatipológián alapul. Mind ez idáig nem került sor az említett fázisok radiokarbon adatokkal való ellenőrzésére. A továbbiakban a közép-európai Barbaricum területére kidolgozott relatív fázisokat használom (GODŁOWSKI 1992; TeJRAL 1992).

44 ISTVÁNOVITS-KULCSÁR 2006.

45 SALAMON-TÖRÖK 1960; LAMIOVÁ-SCHMIEDLOVÁ 1969, 461-463; BUDINSKÝ-KRIČKA-LAMIOVÁ-SCHMIEDLOVÁ 1990;

46 AlmÁssy 2001; AlmÁssy 2009; PIETA 2010, 44-45, 87-88, Abb. $15 b$.

47 PIETA 2010, 184-185, Abb. 80.

48 KOTIGOROSKO 2009.

49 ALMÁssY 2009; Az Északi-Középhegység területét illetően a problémát részletesen tárgyaltuk legutóbbi cikkünkben: SOÓS-TANKÓ 2018b

50 SALAMON-TÖRÖK 1960; JUREČKO 1983; KAMINSKÁ 2005.

51 VÉGH 1964, 52; VÉGH 1985, 106; VÉGH 1989; VÉGH 1999, 219. anyag többségét grafitos situlák töredékei teszik ki, így a típus elterjedését és kronológiáját érdemes lesz az egyéb kerámiatípusoktól függetlenül is megvizsgálni. ${ }^{52}$

A szlovákiai és északnyugat-erdélyi lelőhelyeken dákként azonosított emlékanyag ${ }^{53}$ a magyarországi Przeworsk-területeken nem került elő, ahogy Szabolcs-Szatmár-Bereg megye szarmata területein sem. ${ }^{54} \mathrm{~A}$ korábban dáknak tartott, kézzel formált, durva kerámia formatípusai és a legtöbb plasztikus díszítés, mint az ujjbenyomkodott borda Kr. u. 2-3. századi kontextusból ismert. 55

\section{A Przeworsk-megtelepedés kezdetei és a Severus-kor (B2-B2/C1-C1a)}

A Kárpát-medence északkeleti peremvidékén a császárkor kezdete mind a történeti adatok, mind az anyagi kultúra átalakulása alapján a traianusi dák háborúktól határozható meg. ${ }^{56}$ A dák/kelto-dák hatalmi hálózat szétesésével párhuzamosan jelentek meg az első germán csoportok a térségben.

A terület elfoglalásának katonai jellegére utal, hogy a Kárpát-medencében a B2 fázisra keltezhető legkorábbi Przeworsk jellegú fegyveres temetkezések késő vaskori erődített telepek, ZemplénVárhegy és Mala Kopanya közvetlen közeléből kerültek elő. ${ }^{57}$ A zemplén-szélmalomdombi temető publikációja alapján elterjedt kelta, dák, germán kevert népesség kontinuitása revíziót

52 VÉGH 1985, 5. kép 2; VÉGH 1989, 484; VÉGH 1999, 212, 6. kép 1-2, 6, 7, kép 9, 18, 8. kép 17; LaMiovÁ-SchmiEdLová 1969, 462. A típus a hagyományos LT D keltezéstől eltérően már a LT B2-C1 időszaktól elterjedt (TANKó 2010, 324). Egyes kézmúves termékek továbbélésének lehetőségét Almássy Katalin is felvetette (ALMÁssy 2009, 257). A típus töredékei számos olyan lelőhelyről is ismertek, ahonnan egyéb vaskori jellegú anyag nem adatolt. Nem zárható ki az sem, hogy az 1960-as évek terepi selejtezése miatt magasabb a jellegzetes kerámiatípus aránya a LT töredékek között.

53 LAMIOVÁ-SCHMIEDLOVÁ 1969，458-460; LUŠTIKOVA 2007; GINDELE 2004.

54 MASEK 2012, 257-258.

55 VÉGH 1975, 84; VÉGH 1985, 103; VÉGH 1989, 488; VÉGH 1999 , 212; IstVÁNOVITS 1997, 720-721, Fig. 10, 3, Fig. 11, 1, 3; GindeLE 2013, 12. Szarmata területen a dák jellegúnek tartott emlékanyag szintén hasonló kontextusban azonosítható (VADAY 1996, 156-157).

56 Gindele 2010, 128; Gindele 2013, 11.

57 Ellentétben a felbukkanó 1. századi datálással (KOTIGOROSKO et al. 2004; IstVÁNOviTS-KulCSÁr 2017, 255). A Mala Kopanyán előkerült B1 fázisra keltezhető sír a sodronying maradványával a korábbi dák településhez köthető (KoBÁlY 1998, 116117, 121; VAKULENKO 2008, 164). Zemplén-Szélmalomdomb esetében a temetkezési helyszín is azonos, míg a Mala Kopanya-i erőd melletti dombon elkülönülve kerültek eló Przeworsk sírok (HulLÁm 2012, 85; KотIGOROSKO et al. 2004). 
igényel, jóval valószínúbb, hogy a korábbi késő vaskori temetkezőhelyet használták a később érkező germán csoportok is. ${ }^{58}$ Annak ellenére, hogy bizonytalan a kelto-dák horizont felső időhatára, sem római, sem germán erőszakos pusztítás nyoma nem azonosítható - az újonnan érkező csoportok a rendelkezésre álló stratégiai pontokat hasznosították. ${ }^{59}$

A Przeworsk fegyveres, hamvasztásos síregyüttesek túlnyomó többsége a B2/C1-C1a periódusban, a Kr. u. 2. század második felétól a 3. század első évtizedeiig került földbe, ${ }^{60}$ leletanyaguk szoros kapcsolatot mutat a Lengyelország délkeleti részén szintén ekkor elterjedő Przeworsk-kultúra emlékanyagával. ${ }^{61}$ A kutatás a migrációs hullámot régóta a markomann-szarmata háborúk eseményei közt említett, hasding vandál, victofal és lacring elnevezésú csoportok beköltözésével hozza összefüggésbe. ${ }^{2}{ }^{2}$

A meglepóen alacsony számú, eddig nagyjából 37-38 lelőhelyről ismert, körülbelül félszáz temetkezéssel szemben ${ }^{63}$ a kialakuló településhálózat igen súrúnek tekinthetó, jelenleg ugyanis több mint 300 telepnyomot ismerünk a kultúra Kárpát-medencei területéról. Az elemzett lelőhelyek túlnyomó többsége a B2-B2/C1 periódustól keltezhetó, vagy legalábbis biztosan volt Antoninus- vagy Severus-kori időszaka. Felső időhatáruk azonban a temetkezésekkel ellentétben a késő császárkor végéig követhető.

A pontos kronológia kialakítását nehezíti, hogy a települések leletanyaga kevés átfedést mutat a temetkezésekben előforduló tárgyakkal, valamint a sokáig, megszakítás nélkül lakott lelöhelyeken a hulladék folyamatos felhalmozódása, a viseleti elemek és római import tárgyak hosszú használati ideje miatt a fázisok szigorú elkülönítése nem lehetséges.

Az első germán temetkezésekkel egykorú, B2 fázisra keltezhető településekről kevés adatunk van. ${ }^{64}$ A Magyarország területén feltárt lelőhelyek a markomann háborúk korától, a B2/C1 periódustól keltezhetőek. ${ }^{65}$ Pontosan az időszakhoz

58 BUDINSKÝ-KRIČKA-LAMIOVÁ-SCHMIEDLOVÁ 1990.

59 VAKULENKO 2008, 164; KotigOROSKO 2009; GINDELE 2013, 13.

60 Hullám 2012, 92.

61 MAdydA-LegUtKO-RODZIŃKA-NOWAK 2012; MADYDA-LEGUTKO et al. 2013.

62 GODŁOWSKI 1984.

63 GODŁOWSKI 1993; HulláM 2012. A leletek bizonytalan régészeti kontextusa miatt a síregyüttesek a legtöbb esetben nem különíthetőek el.

64 Gindele-IstVÁnOVITS 2009, 51-52; Gindele 2010, 128-131, Abb. 62; GINDELE 2013, 14, Taf. I.

65 Nem lehet kizárni, hogy egyes telepek, mint GaradnaKovács-tanya vagy Beregsurány-Barátságkert már a Kr. u. 2. század közepe előtt létezhettek, de biztosan csak B2/C1 periódustól tudunk keltezni. tartozó jelenségeket és teleprészleteket leválasztani egyelőre nem lehetséges, az import darabok gyakran a Kr. u. 3. század első évtizedeire keltezhetó egyéb leletekkel együtt kerülnek elő.

A legkorábbi eredetú importtárgyak - egy Garadna-Kovács-tanyai Faustina dénárt leszámítva ${ }^{66}$ - a római üvegleletek. A Beregdaróc-Zsid lelőhelyen talált bordás tál vagy tárolóedény és a tálka töredékei a Kr. u. 1. század második fele és a 2. század első fele közt készülhettek, a feltáró szerint azonban a markomann háborúk korában kerültek földbe (4. kép 1-2). ${ }^{67}$

Hernádvécse-Nagy-rét lelőhelyről egy áttetsző üvegzöld színú, hasábos testú palack töredéke került elő (4. kép 3), mely színe alapján a Kr. u. 2. század második felében, a 3. században lehetett használatban. ${ }^{68}$

Szintén Hernádvécsén került elő egy korai, magas peremlécú dörzstál, melyhez hasonló darabok provinciális területen a Kr. u. 2. század 2-3. negyedére keltezhetóek (4. kép 4). ${ }^{69}$

Garadna-Kovács-tanyáról több szürke agyagmázas, díszítetlen vagy fogaskerékmintás, Drag 37-es formát utánzó tál (Pannonische Glanztonwäre, $P G W$ ) ismert (4. kép 5, 7). A hasonló agyagmázas felületú edények provinciális területen a Kr. u. 1. század második felétől a 3. század elejéig voltak jellemzőek, a budaörsi vicus területén általában Hadrianus-Antonius koriak, de használatuk a Severus-korban is gyakori. ${ }^{70}$ Barbaricumi példányaik esetében az utóbbi, késői keltezést valószínúsítik. ${ }^{71}$

A provinciális áruk szintén korai darabjait a festett sávos kerámiatöredékek jelentik (4. kép 6, 8). A brigetiói múhely virágzását és a pannóniai gyártásukat a Kr. u. 2. század második felére és a 3. század elejére helyezte a kutatás. ${ }^{72}$ A szarmata Barbaricumban a 2. század második felétól terjedtek el nagyobb számban, a kelet-szlovákiai Przeworsk-lelőhelyeken előkerült darabok keltezése is ennek megfelelő. ${ }^{73}$

A B2/C1-C1a periódusra keltezhető kistárgyak másik része barbaricumi eredetú. Egy Garadna-Kovács-tanyai kisméretú térdfibula kéttagú, keskeny, félkörös fejlappal ellátott, felsőhú-

66 CSENGERI-PuszTAi 2008, 16-17. kép.

67 PINTYE 2010, 109-110, 25. ábra 8, 29. ábra 8, 42. ábra 8.

68 Lásd: IsINGS 1957, 63, Form 50, 108, Form 90; DÉVAI 2012, 191-192. A tanulmányban szereplő publikálatlan üvegleletek meghatározását dr. Dévai Katalin (ELTE BTK RI) végezte el. Kedves segítségét ezúton is köszönöm.

69 GroH-SEDLMAYER 2002, Abb. 136; OTtOMÁNYi 2012, 236.

70 OTTOMÁNYI 2012, 212-213.

71 LAMIOVÁ-SCHMIEDLOVÁ 1969, 480; JUREČKO 1983, Obr. 40, 3; KuZMOVÁ-RÁKOS 2016, 168.

72 BóNIS 1970, 78-80, 1, 4-5. ábra; KELEMEN 1980, 58.

73 SósKuti-WiLHelm 2014, 69; KuZMOVÁ-RÁKOS 2016, 168. 


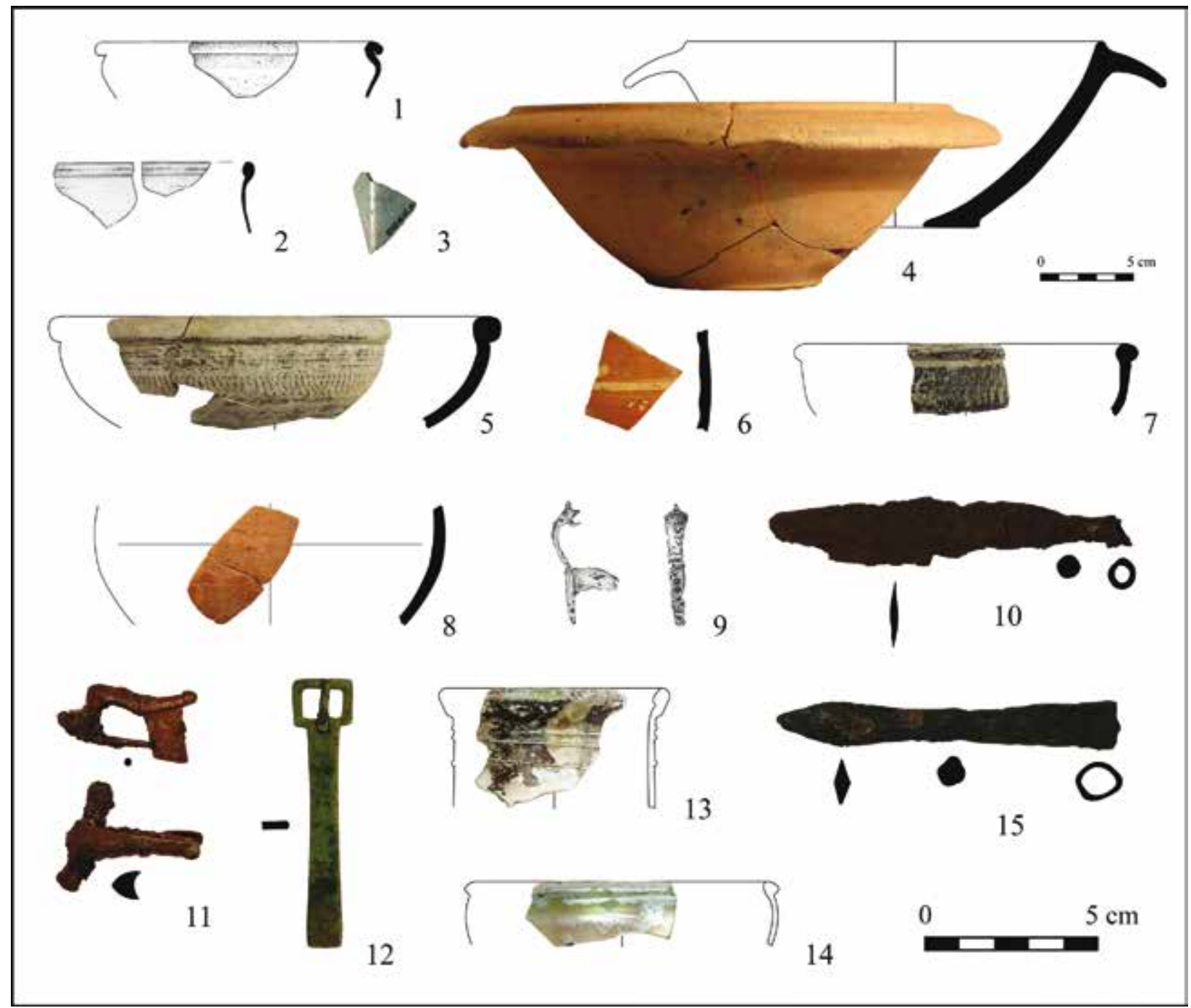

4. A B2/C1-C1a periódus leletei a Przeworsk-településeken. 1-2., 9. Beregdaróc-Zsid; 3-4., 8. Hernádvécse-Nagy-rét; 5-7. 10-15. Garadna-Kovács-tanya (1-3., 9., 11-14. méretarány: 1; 4-8., 10., 15. méretarány: 2)

Fig. 4. Finds of Period B2/C1-C1a on the Przeworsk settlements. 1-2., 9. Beregdaróc-Zsid; 3-4., 8. Hernádvécse-Nagy-rét; 5-7., 10-15. Garadna-Kovács-tanya (1-3., 9., 11-14. scale: 1; 4-8., 10., 15. scale: 2 )

ros, erősen megtört kengyelú, lába gombban végződik (4. kép 11). A provinciális területen Kr. u. 2. század harmadik negyedétől készített térdfibulák többsége nagyméretú, félkörös vagy szögletes fejlappal rendelkezik, a lábvég kialakítása egyenes. ${ }^{74}$ Ezek a római típusok szarmata és germán területen is széles körben elterjedtek. ${ }^{75}$ A garadnai fibula igen keskeny fejlapjának kialakítása a Kovrig 104/104a típusokéra emlékeztet, melyek Pannónia északi részén készülhettek és az ún. germán térdfibulák elóképeként szolgáltak. ${ }^{76} \mathrm{~A}$ kengyel gombos végződése barbaricumi

74 Cociş 2004, 90; Merczi 2011, 7; Merczi 2012, 507, 7. kép.

75 Vaday 1989, Abb. 13; DroberJar 2012, Obr. 1-2.

76 Kovrig 1937, 104. típus,121, X. t. 104; MĄCZYŃSKA 2001, 79, Abb 1, 1, 3 . területen sokkal gyakoribb az ún. „szarmata” típusú számszeríjfibulák esetében. ${ }^{77} \mathrm{Az}$ analógiák alapján a példány szintén a Kr. u. 2. század végére, a 2-3. század fordulójára keltezhetó.

Ugyanebben az időszakban lehettek használatban a Beregsurány-barátságkerti és Beregdaróc-zsidi, Almgren VII. csoportba tartozó, magas tútartójú, kéttagú, ún. „szarmata” típusú bronz számszeríjfibulák (4. kép 9). ${ }^{78}$ Az elnevezésével ellentétben germán, legnagyobb valószínúséggel Przeworsk-területekről eredeztethető fibulatípus a Kr. u. 2. század utolsó évtizedeitől terjedt el a kultúrkör törzsterületétól délre és keletre. A Közép- és a Felső-Tisza-vidéken, szarma-

77 COCIŞ-BÂRCĂ 2014, 196, 203, Fig. 6.

78 IstVÁnOVITS 1997, 720, Fig. 7; PinTYE 2010, 110, 38. ábra 1. 
ta és germán környezetben előkerült darabok használati idejét általában a Kr. u. 2. század utolsó évtizedei és a 3. század közepe közé, a C1a$\mathrm{C} 1 \mathrm{~b}$ periódusra helyezi a kutatás. ${ }^{79}$

Garadna-Kovács-tanyán két lándzsahegy is napvilágot látott. Az egyik, középső harmadában szélesedő pengéjú lándzsa (4. kép 10) a Kaczanowski-féle XIII. típushoz áll közel, mely a lengyelországi hamvasztásos temetkezésekben a B2/C1-C1a fázisokra jellemz̋o. ${ }^{80}$ Hasonló kialakítású fegyverek a Kárpát-medencében a Kr. u. 2. század második felére keltezett szolyvai leletból ismertek. ${ }^{81} \mathrm{~A}$ másik, rövid, rombusz átmetszetú pengéjú, hosszú köpújú garadnai lándzsatípus (4. kép 15) lengyelországi Przeworsk-területen szintén a B2/C1 időszakra volt jellemző, a legtöbb példány a $\mathrm{B} 2$ periódusra datálható. ${ }^{82}$

Biztosan szarmata területról érkezett importként csak egy Garadna-Kovács-tanyai, egytagú szarmata csat határozható meg (4. kép 12). A csattípus a Kr. u. 2. század végétől terjedt el szarmata területen, legészakabbi példányai a Nyírségből ismertek. ${ }^{83}$ A garadnai darab a Vaday Andrea és Kulcsár Valéria által meghatározott I. típus 2. csoportjába sorolható, így a Kr. u. 2. század utolsó két évtizede és a 3. század első negyede közé keltezhető. ${ }^{84}$

A Kr. u. 2. század végére és a 3. század első felére római üvegleletek is utalnak. GaradnaKovács-tanyáról egy áttetsző sárgászöld, hengeres üvegpohár pereme ismert (4. kép 13), mely a Kr. u. 2. század harmadik negyedétől a 3. század közepéig keltezhető. ${ }^{85}$ Pannóniából, Brigetióból és Intercisából kerültek elő példányai, melyek használata a 3. század elejére tehető. ${ }^{86}$

Valamivel késóbbi keltezésú egy szintén garadnai, áttetsző üvegzöld, körte vagy konvex testú pohár (4. kép 14). ${ }^{87} \mathrm{~A}$ típus a Duna-vidéken nem gyakori, Pannónia területéról szintén csak

79 VAdAY 1989, 78; IsTVÁNOVITS 1990, 103; CoCIŞ 2004, 134, Type 32a2a1; Cocış-BÂrCĂ 2014, 196, 203, Fig. 6.

80 KACZANOWSKI 1995, 22, Tabl. XI, 3-4, Tabl. XX.

81 KoBÁLY 1998, 122, VIII. t. 2-3.

82 KacZanowski 1995, 21, Tabl. XI, 1-2, Tabl. XX; Kontny 2008, Fig. 10. A formatípus szarmata kontextusban a Kr. u. 3. századra jellemző, de későbbi keltezése sem zárható ki (VADAY 1989, 113).

83 VADAY-KULCSÁr 1984, Abb. 9; VADAY 1989, Abb. 9; IstVÁNOVITS 1990, 97-98, XVIII. T. 2, XX. T. 1, 3, XXI. T. 1, 5, XXII. t. 1; ISTVÁNOVITS-KULCSÁR 2002, 95.

84 VADAY-KUlCSÁR 1984, 165. jegyzet, Abb. 1, 13; DinNYÉs 1991, 164-166.

85 IsINGS 1957, 102-103, Form 85b; COTTAM-PRICE 1998, 99-100; DÉVAI 2013, 95-96.

86 BARKÓCZI 1988, 69-70, Form 29 (Kat. 60)

87 CotTAm-Price 1998, 103-104, Britannia provinciában 2. századi példányok ismertek.
Brigetióból és Intercisából ismert két példány, mindkettő a 3. századra keltezhető. ${ }^{88}$

A Przeworsk-településeken a legnagyobb számú provinciális importot a terra sigillata töredékek jelentik, a Felsô-Tisza-vidékre pár középgalliai töredéken kívül szinte kizárólag a felsőgermániai és az Inn menti múhelyek termékei jutottak el.

Az Arka-Fónyi-patak lelőhelyen feltárt épület betöltéséből 2 Drag. 37-es tál töredéke került elő, melyeket korábban Gabler Dénes rheinzaberni terméknek határozott meg, újabb feldolgozásában Gyalai Zsófia a lezoux-i múhely késői darabjának tartotta, de szintén a Kr. u. 2. század utolsó évtizedeitől keltezte. ${ }^{89}$

A rheinzaberni múhelyben készült terra sigillata edények töredékei csaknem mindegyik magyarországi település leletanyagából elókerültek (5. kép 1-3). A Garadna-Kovács-tanyai darabok finom kivitelezése a múhely Antoninuskori múködésére utal..$^{90} \mathrm{~A}$ Kelet-Szlovákia területét taglaló újabb elemzések alapján a rheinzaberni sigillaták egy részét a markomann-szarmata háborúk időszakára lehet keltezni, túlnyomó többségük azonban Severus-kori. ${ }^{91} \mathrm{Az}$ arkai, hernádvécsei, beregdaróci és a Garadna-kastély-zugi töredékek esetében is a Kr. u. 3. század eleji keltezés valószínúsíthetô. ${ }^{92}$

Hasonló a helyzet a Kr. u. 2. század utolsó harmada és a 3. század első harmada közt múködő westerndorfi múhely termékeivel, melyek a legnagyobb részét teszik $\mathrm{ki}$ a magyarországi Przeworsk-települések terra sigillata anyagának (5. kép 4-7). Töredékeik általában a 3. század első évtizedeire keltezhetőek..$^{93}$

A pfaffenhofeni múhely termékei jóval alacsonyabb számban fordultak elő. ${ }^{94}$ Nagyobb menynyiségben csak Garadna-Kovács-tanyán kerültek elő (5. kép 8-10), ott Gyalai Zsófia a Kr. u. 3. század első kétharmadára helyezte használatukat. ${ }^{95}$

Fontos hangsúlyozni, hogy a nagyszámú importtárgyat adó településeken, mint GaradnaKovács-tanyán a rheinzaberni és westerndorfi terra sigillaták, a vörös sávos festésú töredékek

88 BARKÓCZI 1988, 77, Form 40 (Kat. 82).

89 GABLER 1968, 214; Soós 2017, 33; GYALAi 2012, 14-16.

90 Gyalai 2009, 359.

91 KuZMOVÁ 2014, 173; KuZMOVÁ-RÁKOS 2016, 165-166.

92 Gabler 1968, 217, 2. kép 1; Gyalai 2009, 364; ArdeleANU 2014, Table 1.

93 Gabler 1968, 214; Gyalai 2009, 358; KuZMOVÁ 2014, 173; Soós 2017, 33.

94 Ardeleanu 2014, 18-19, Graph. 7.

95 Gyalai 2009, 364, 3. táblázat. A keltezés Dacia provincia 271-es feladásán alapszik, ám ez nem biztos, hogy egyenes összefüggésbe hozható a germán területek felé irányuló római export csökkenésével. 


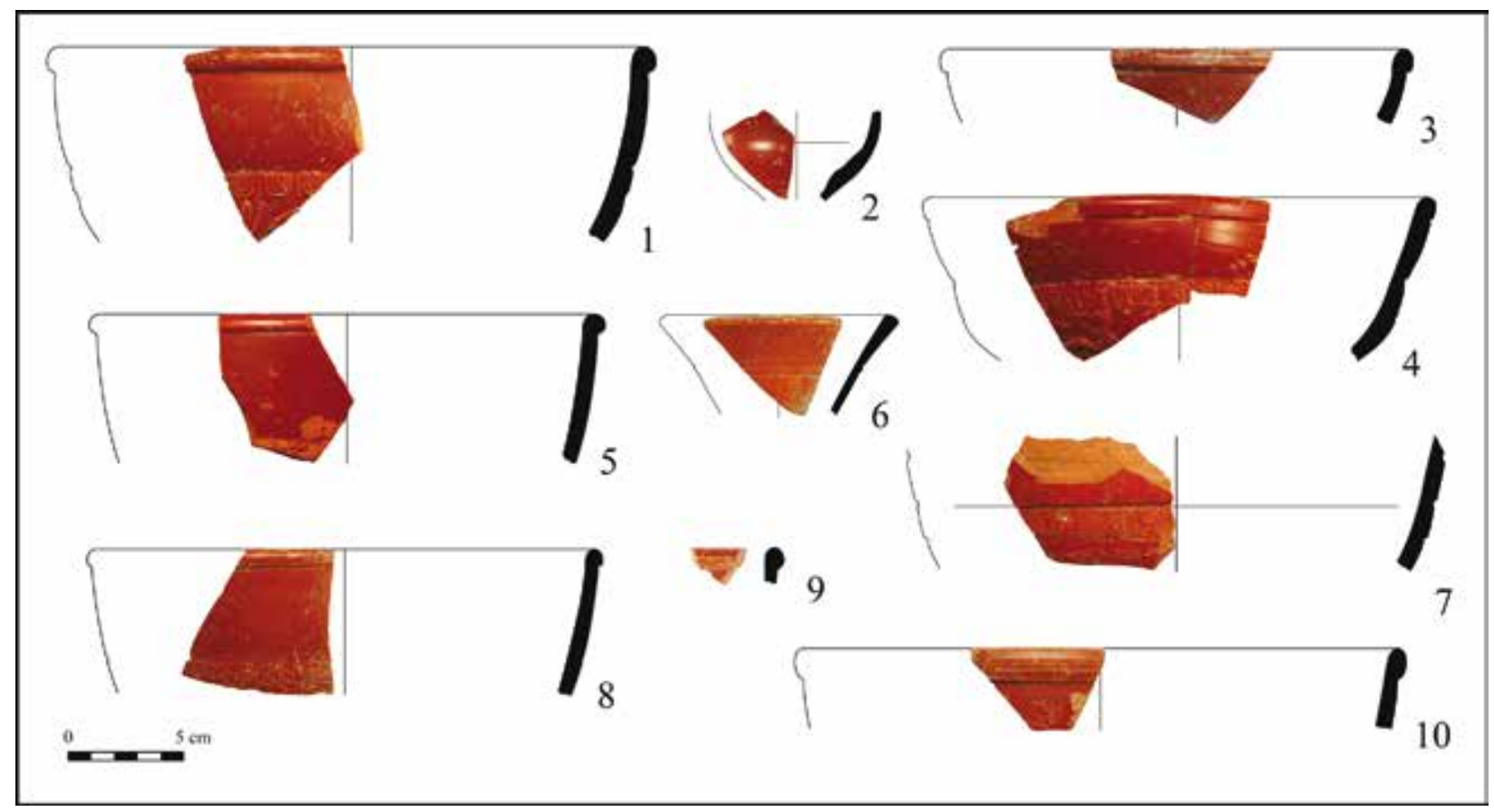

5. kép. Terra sigillata leletek. 1-3. Rheinzabern; 4-7. Westerndorf; 8-10. Pfaffenhofen. 1-4., 6-8., 10. Garadna-Kovács-tanya; 5. Hernádvécse-Nagy-rét; 9. Mezőzombor-Temető

Fig. 5. Terra sigillata finds. 1-3. Rheinzabern; 4-7. Westerndorf; 8-10. Pfaffenhofen; 1-4., 6-8., 10. Garadna-Kovács-tanya; 5. Hernádvécse-Nagy-rét; 9. Mezőzombor-Temető

és részben a szürke firniszes tálak az esetek nagy többségében ugyanabból a kontextusból kerültek napvilágra, időrendjük így nem minden esetben elválasztható. ${ }^{96}$

\section{A római késő császárkor (C1-C2, C3)}

A leletanyagban számos tárgytípus a C1-C2 perióduson belül nem datálható pontosabban, így a települések Kr. u. 3. századi fejlődése csupán tágabb időhatárok közt tagolható. Erôsebb kronológiai támpontot a C3-C3/D1 leletei jelentenek.

A telepekről ismert fibulák túlnyomó többsége Almgren VI. 158 típusú, egytagú, felsóhúros, aláhajtott lábú példány, melyek ismertek GaradnaKovács-tanyáról, Hernádvécséről, Beregdarócról is (6. kép 1-3). ${ }^{97} \mathrm{~A}$ típus eredete szintén Przeworskterületen kereshetó, példányai a Kr. u. 2. század végétől, a Cla periódustól, a germán terjeszkedéssel párhuzamosan jelentek meg széles körben, a szarmata Alföldön, Szlovákia és Morvaország területén is nagy számban megtalálha-

96 Ajelenség szarmata területen szintén megfigyelhető (GABLERVADAY 1992, Abb. 29). Vác-Csörögi-rét lelőhelyen pl. ugyanabból a kontextusból Kr. u. 150-250 közé datálható terra sigillata, valamint kétoldalas agancsfésú és kéttagú, aláhajtott lábú fibula került elő, melyeket nem lehet a Kr. u. 4. századnál korábbra keltezni (KuLCSÁR-HoRVÁTH 2002, 319).

97 PINTYe 2010, 110, 35. ábra 6. tóak. Használatuk a C2 periódus végéig megfigyelhető, ezen hosszabb időszakon belül azonban pontosabb keltezésük nem lehetséges. ${ }^{98}$ Gindele Róbert használatukat erdélyi Przeworskterületen még a C3 periódusban is valószínúnek tartja. ${ }^{99}$

Az ívelt hátú, többtagú agancsfésúk szintén nem jelentenek pontos kronológiai fogódzót a késő császárkoron belül. Kvád településeken a C1 periódustól bukkannak fel, használatuk a Kr. u. 4-5. század fordulójáig követhető. A magyarországi példányok valószínúleg a Kr. u. 3. században kerülhettek földbe. Elófordulásuk a Zempléntól nyugatra gyakoribb, Garadnán hat, Mezőzomboron egy fésú töredékei kerültek elő (6. kép 4-7). A Szamos-síktól keletre jóval kevesebb példány ismert. ${ }^{100}$

Garadna-Kovács-tanyáról két egytagú, felsőhúros, Almgren VII. csoportba tartozó, oldalt hajtott lábú fibula is előkerült (6. kép 8). A formatípus az egyszerú, aláhajtott lábú példányokhoz hasonlóan széles körben elterjedt a Przeworsk-

\footnotetext{
98 VADAY 1989, 86, Abb 15, 1-2; VAKULENKO 1998; Cociş 2014, 131.

99 Gindele 2010, 137-139, Abb. 66

100 TejRal 2008, Obr. 10-12; PINTYe 2009; Gindele 2010, 136-141, Abb. 65-67; MASEK 2016, 115-116, Fig. 6, Fig. 17.
} 

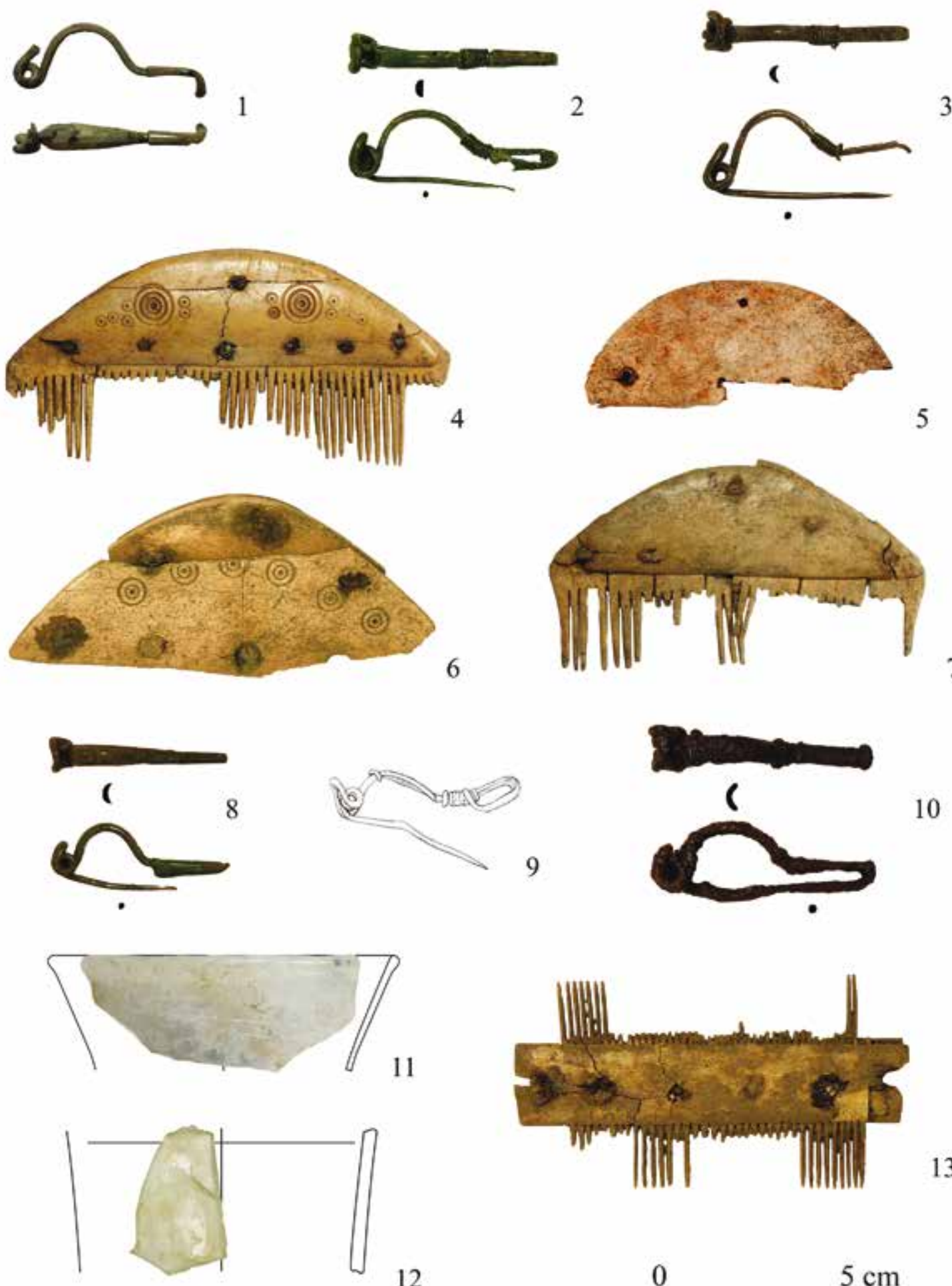

12

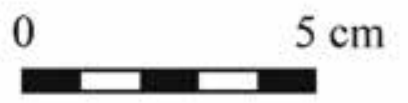

6. kép. A C1-C2 és a C3 periódus leletei a Przeworsk-településeken. 1. Hernádvécse-Nagy-rét; 2-4., 6-8., 10-11., 13. GaradnaKovács-tanya; 5. Mezőzombor-Temető; 9. Bodrogkeresztúr; 12. Garadna-Kastély-zug

Fig. 6. Finds of Period C1-C2 and C3 on the Przeworsk settlements. 1. Hernádvécse-Nagy-rét; 2-4., 6-8., 10-11., 13. GaradnaKovács-tanya; 5. Mezőzombor-Temető; 9. Bodrogkeresztúr; 12. Garadna-Kastély-zug 
kultúra dél-lengyelországi régióiban, a Dunavidéki germán Barbaricumban és szarmata területeken is. Példányai a Kárpát-medence északi részére jellemzőek inkább, a Tokaj-Szepesi-hegységtől keletre ritkábban fordulnak elő. ${ }^{101} \mathrm{~A} \mathrm{Kr}$. u. 300 körüli dátumra helyezett strážei 1 . fejedelmi sírból ezüst díszpéldánya ismert, ez alapján akkor már divatban volt. ${ }^{102} \mathrm{~A}$ legtöbb területen a C2-C3 periódusokra, a Kr. u. 3. század második felére és a 4. század elsó évtizedeire keltezhetőek. ${ }^{103}$

Szintén a strážei 1. temetkezésből ismert egy Garadna-Kovács-tanyai, kengyelének végein csavart drótdíszítéssel ellátott, Almgren VI. 166 aláhajtott lábú, régebbi nevén „magyar" típusú vasfibulának a formai analógiája (6. kép 10). A típus bronz példányai, mint a bodrogkeresztúri darab is (6. kép 9)104 a C2-D1 periódusokban voltak elterjedtek, a legtöbb darab a Kárpát-medence északkeleti részén a C3 periódusra tehető. ${ }^{105}$

A Kárpát-medencei Przeworsk-települések egy része biztosan megérte a római császárkor végét. Magyarország területén Garadna-Kovácstanya lelőhelyről kerültek elő olyan leletek, melyek nem keltezhetőek a Kr. u. 4. század utolsó évtizedeinél korábbi időszakra. Egy agyagnyerő gödörből látott napvilágot egy díszítetlen, kétoldalas, többtagú agancsfésú (6. kép 13). A típus legkorábban a Kr. u. 4. század utolsó évtizedeiben bukkant fel Pannónia területén, ${ }^{106}$ de az észak-magyarországi germán lelőhelyek példányai is ugyanekkor kerülhettek földbe. ${ }^{107}$ Egy színtelenített, széles, kúpos testú üvegpohár fehéres peremtöredéke szintén a Kr. u. 4. század középső harmadára keltezhető (6. kép 11).108

A közeli Garadna-Kastély-zugi település leletanyagában szintén volt egy áttetsző-fehér színú, vésett hatszögekkel, azokon belül facettált ovális mintákkal díszített, amfora vagy kúpos testú pohár töredéke (6. kép 12). A keleti tartományokban és Pannoniában a pohárforma és a díszítésmód analógiái is megtalálhatóak a Kr. u. 4. század középső harmadától, de egyes darabok az 5. század elejéig is keltezhetőek. ${ }^{109}$

101 Cocış 2014.

102 KREKOVIČ 1992, 57, Abb. 4, 1.

103 PeŠKar 1972, 118-119, Taf. 34; VAdAY 1989, 90; GodŁowSKI 1992, 42; VARSIK 2011, 194-199, Abb. 104

104 VÉGH 1975, Taf, II, 7.

105 PeŠKar 1972, 112-113, Taf. 30; PIETA 1999, 185, Taf. 13, 5; MĄCZYŃSKA 2001, 81, Abb. 2, Abb. 4.

106 Összefoglalóan: MASEK 2016, 106-107, Fig. 17.

107 PinTYe 2009, 169, 5. kép 3. és 4. kép. Pl. Vác-Csörögi rét (KulCSÁr 2004, 229, Fig. 2); Urziceni-Vamă (GiNDELE 2010, 141, Abb. 67).

108 BARKÓCZI 1988, 83; DÉVAI 2012, 163-164.

109 BARKÓCZI 1988, Form 47; DÉval 2012, 161, 194, 197-198.
A Magyarországon feltárt Przeworsk-települések időrendje

A kronológiai támpontok bizonytalanságait is figyelembe véve megközelítőleg körvonalazható a magyarországi települések időrendje (7. kép).

A régióból nem került elő olyan településlelet, mely a Kr. u. 2. század második felénél korábbi keltezést tenne lehetővé. A B2/C1 periódusra jellemző leletanyag szinte minden lelőhelyről ismert, bár hangsúlyozni szükséges, hogy az időszak a leletanyag alapján nem választható el pontosan a Cla periódustól.

Garadna-Kovács-tanya esetében a kronológiai támpontot jelentő tárgyak többsége a B2/C1 időszakra tehető. A település szerkezete és az anyagi kultúra sajátosságai alapján valószínú, hogy ez nem az alapítás időszaka: az esetleges korábbi teleprész a feltárt felületen kívül helyezkedhet el. Annak ellenére, hogy a Kr. u. 3. század második felének meghatározása bizonytalan, mivel az aláhajtott lábú fibulák, fésúk „visszahúzhatóak” a század első felére is, a település feltehetően megszakítás nélkül tovább élt a Kr. u. 4. század utolsó harmadáig.

A feltárt teleprészletek egy része hasonló Garadna-Kovács-tanyához, ezeket a leletanyag alapján provinciális kapcsolatokat is fenntartó, gyorskorongolt edényeket széles körben használó csoportok létesítették.

Arka-Fónyi-patak lelőhely épülete szintén olyan leletanyagot örzött meg, mely a B2/C1 fázistól jellemzó a régióban. A teleprészlet a hombárok magas száma és formái alapján a $\mathrm{Kr}$. u. 3. század első, talán második felében is követhető. ${ }^{110}$ A Mezőzombor-Temető lelőhelyen előkerült császárkori leletanyag az arkaihoz hasonló

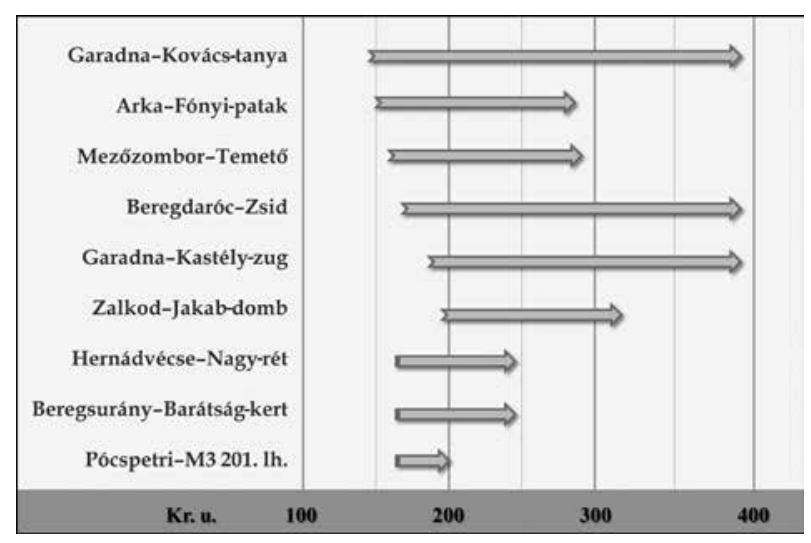

7. kép. A Magyarországon feltárt Przeworsk-települések időrendje

Fig. 7. Chronology of the Przeworsk settlements uncovered in Hungary

110 Soós 2017, 35. 
keltezést tesz valószínúvé. Beregdaróc-Zsid lelőhely korai fázisa szintén a B2/C1 időszakra tehető. ${ }^{111}$

Néhány lelőhely esetében, mint GaradnaKastély-zug és Zalkod-Jakab-domb, valamivel későbbi, inkább Kr. u. 3. század eleji keltezés valószínú, míg felső időhatáruk nem zárható le a késő császárkoron belül. ${ }^{112}$

A feltárás során előkerült Przeworsk-telepek másik része szintén a $\mathrm{B} 2 / \mathrm{C} 1$ időszakban létesült, de eltérő hagyományokat mutat. A markomann háborúk során a területre érkező csoportok nyoma Magyarországról Hernádvécse határából ismert. A lelóhely felső időhatára szintén homályos, a tárgyak analógiái nem mutatnak a Kr. u. 3. század első felénél, esetleg első harmadának végénél késóbbi kapcsolatokat. A leletanyaga alapján Beregsurány-Barátság-kert szintén a markomann háborúk alatt jött létre és a szarmata típusú számszeríjfibula alapján a 3. század első felét is megérte. ${ }^{113}$ Fontos említést tenni az ugyanezen horizonthoz tartozó, de szarmata településterületen előkerült, egyetlen pócspetri leégett épületról, melynek kézzel formált kerámia leletanyaga a csengersima-peteai telep korai fázisával rokon. ${ }^{114} \mathrm{Az}$ együttes lényeges bizonyítéka annak, hogy a Przeworsk-foglalás bizonyos idóben szélesebb területen jelentkezett, mint annak késóbbi elterjedési zónája. ${ }^{115}$

A két eltérő településtípus valószínúleg összefüggést mutat a Przeworsk-kultúrkör hordozóinak több hullámban való megtelepedésével a Kárpát-medencében. A kutatásban többször felmerült, hogy a Kr. u. 2. század folyamán már a Felső-Tisza-vidéken élő népességhez a markomann-szarmata háborúk során újabb betelepülő csoportok érkeztek. ${ }^{116} \mathrm{Az}$ interpretáció főként időrendi szempontból kíván még alátámasztást, a két településtípus az újabb kutatások alapján egyaránt a B2/C1 periódustól keltezhetó. Mindenesetre a két csoport anyagi kultúrája, épülettípusai, gazdálkodási módja, a kézzel formált kerámia formavilága, valamint a telepek egymáshoz közeli elhelyezkedése, az ellenséges viszony nyomainak teljes hiánya azonos kulturális háttérról tanúskodik.

111 PINTYe 2010, 111-112.

112 Előbbi esetben a kúpos üvegpohár egészen késői datálást is felvethet (Soós 2014, 146, 147).

113 IsTVÁNOVITS 1997.

114 MASEK 2012, 239-240, 254-255, 30-31. tábla, 37. tábla 8-14, 39. tábla 1.3 .

115 A Heves megyei Sirok és Terpes lelóhelyeken előkerült síregyüttesek régiójából szintén nem ismert Przeworsk-település.

116 LAMIOVÁ-SCHMIEDLOVÁ 1969, 492; LAMIOVÁ-SCHMIEDLOVÁ 1992, 78; VAKULENKO 2008, 175; GINDELE 2013, 19; GINDELE 2014.

\section{Az anyagi kultúra változása}

A relatív időrendi támpontok meghatározása után lehetóség nyílt a korábban etnikai alapon besorolt anyagi kultúra új értelmezésére. A nagy felületú feltárások leletanyaga jórészt pontosan dokumentált kontextusból került elő, így kirajzolódtak az egyszerre szemétbe került (egyes esetekben in situ) és valószínúleg egyszerre használatban volt tárgytípusok.

A telepanyagok túlnyomó többségét jelentő kerámiaanyag jellemzői nem etnikai különbségeket, hanem elsősorban funkcionális eltérést mutatnak.

A rekonstruálható edénykészlet változatos összetételú volt. Fogyasztási vagy díszítési célokat eleinte kizárólag a kézzel formált, finom, fényezett, feketére égetett Przeworsk-edények szolgáltak. A korai időszakban igen jellegzetes, éles hastörésú tálakat, bikónikus vagy félgömbös aljú tálkákat, erós profilú fazekakat találunk az anyagban. Helyi elóálításuk miatt a típusok formavilága akár településenként is mutathat variációkat. A korábbi kutatási eredményekkel ellentétben használatuk a Kr. u. 3. században is megfigyelhető, de telepen belüli arányuk idővel erősen csökken. Idővel az éles profilok kerekebbé válása figyelhetó meg, mint a Garadna-Kovácstanyai tálak esetében, illetve a kisméretú edénykék eltúnnek az anyagból (8. kép).

Szintén helyben készültek a kézzel formált, durva főző- és tárolóedények, legnagyobb számban fazekak. Megfigyelhetó, hogy a korai időszakban a felső harmadban szélesedő, bikónikus formák voltak használatban, melyek mellett nagyméretú, szúk szájú, erősen hasasodó edények is feltûntek. A késő császárkorban a fazekak profilja íveltebbé vált, a középen hasasodó, egyszerú S-profilú edények tették ki az anyag nagy részét. A tálak esetében szintén megfigyelhető egy tendencia a bikónikus formáktól az íveltebb profilokig. Elsősorban a Zempléntől nyugatra, a korai idószakban durva anyagból számtalan edénytípust formáztak: kisméretú és nyúlánk fazekakat, bögréket, fedokket, kis tálakat, miniatűr edényeket és széles, lapos sütőtálakat is. Idővel a széles formai spektrum leszúkül, a késő császárkorban jórészt csak a fazekak és a tálak maradtak használatban (8. kép).

A Kárpát-medencei Przeworsk-településeken, ellentétben a kvád kultúrkörrel,117 viszonylag korán, a Kr. u. 2. század második felétől, valószínúleg daciai provinciális hatásra megindult és széles körben elterjedt a gyorskorongolt kerámia

117 ŠVAŇA 2011. 


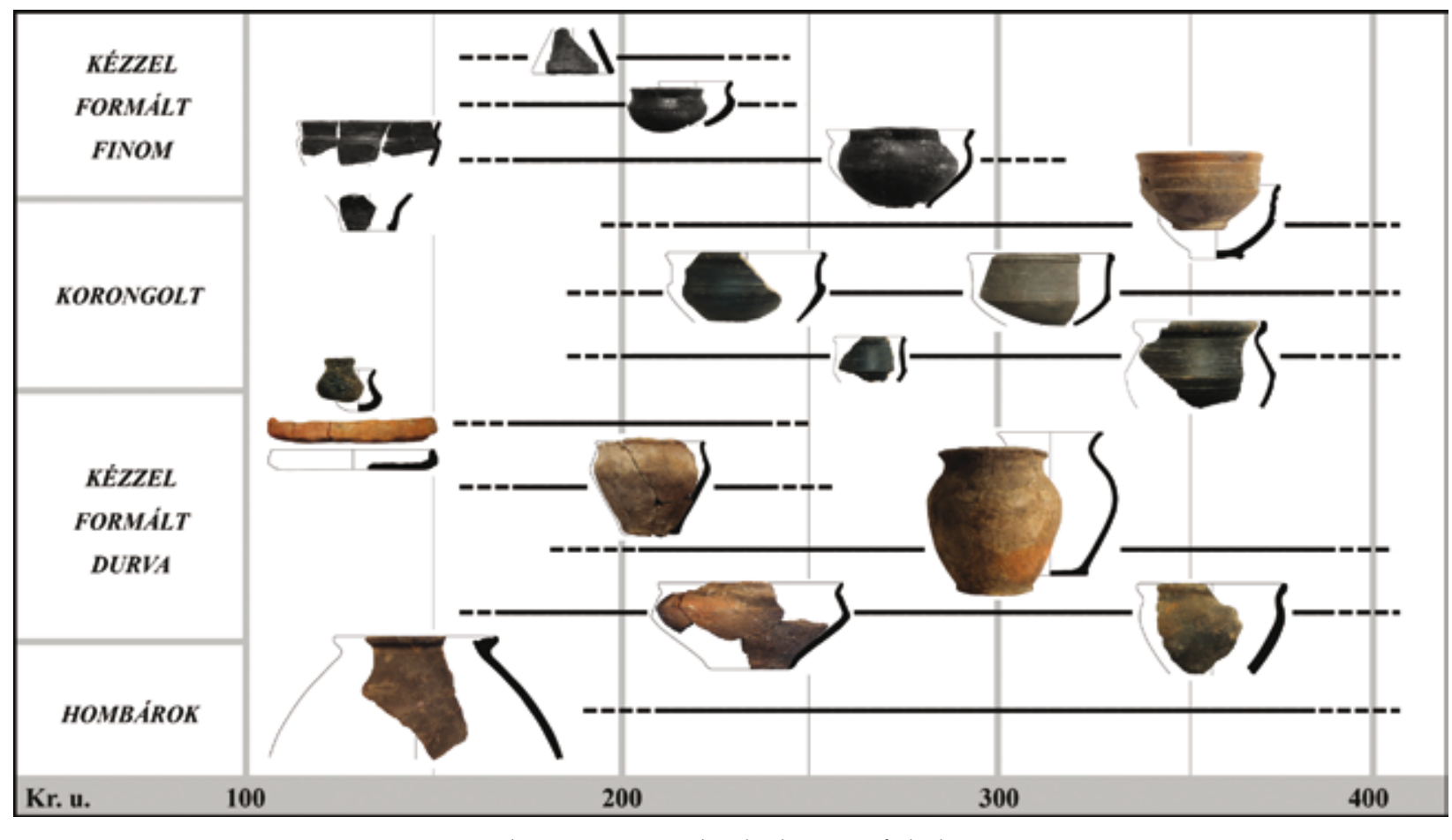

8. kép. A Przeworsk-telepkerámia fejlődése

Fig. 8. Development of Przeworsk settlement pottery

helyi gyártása és használata. A finom és durva, kézzel formált áruval szemben a korongolt edények előállítása nem az egyes településeken, hanem specializálódott fazekasmúhelyekben történt, melyek bizonyos piackörrel rendelkezhettek. A legnagyobb számban tálak készültek az anyagból, ezeket egészítették ki a folyadéktároló edények: korsók, poharak, és kisebb számban a fazekak különböző típusai. A korai korongolt anyagban feltúnnek olyan darabok, melyek a finom, fekete, Przeworsk-edények éles profilját imitálják. Tehát nem a korongolt kerámiát gyártó múhelyek termékei befolyásolták a helyi kézmúvességet, hanem a germán anyagi kultúrában megszokott, bikónikus formákat próbálták gyorskorongolt technológiával elóállítani. A folyamat egy sajátos, az alföldi szarmata fazekasságtól elkülönülő kerámiamúvességet hozott létre.

A korongolt edények körében a Kr. u. 3. századtól feltúnnek vastagabb falú, szemcsés anyagú fazekak, ritkábban tálak, korsók is. ${ }^{118}$ Töredékeik alacsony számban szinte minden településen megtalálhatóak. A hasonló kivitelú, szemcsés gyorskorongolt főzőedények a késő császárkor végén váltak igazán elterjedtté, ${ }^{119}$ ám

\footnotetext{
118 Šebastovce-Barca lelóhelyen helyi előállítását egy kemence is bizonyítja (LAMIOVÁ-SchMiedLová 1969, Abb. 25, Abb. 31; LUŠTIKOVÁ 2013, Tab. IX).
}

119 Gindele-IstVÁNOVITS 2009, 50-51. egyelőre nem állapítható meg, hogy a késői tömegtermékek milyen kapcsolatban álltak a korai darabokkal.

A Przeworsk-telepeken tárolás céljára elsősorban nagyméretú, vastag falú, széles, vaskos, árkolt peremú hombárok szolgáltak, melyeket a magyarországi szakirodalom „északi típusúnak” nevezett, elkülönítve azokat a szarmata hombároktól. ${ }^{120}$ A $80-120 \mathrm{~cm}$ magasságú, súlyos edények technológiai és formai jegyei mind ez idáig nem mutattak kronológiai eltéréseket. A hombárok elóállítása és kiégetése speciális technológiával történt, feltehetóen minden darab egyedi terméknek tartható, így tipokronológia kidolgozása csak korlátozottan lehetséges. Eredetük és cserehálózatuk kevésbé kutatott, az aranyosmeggyesi (Medieşu Aurit-i), Kr. u. 2. századtól múködő, nagyrészt hombárokra szakosodott fazekastelep feldolgozása számos új információt fog nyújtani a kutatás számára. ${ }^{121}$

\section{A regionális kapcsolatok}

A Kárpát-medencei Przeworsk-települések anyagi kultúrája regionálisan eltéró fejlődést mutat; különbség figyelhető meg például az Eperjes-

\footnotetext{
120 ISTVÁNOVITS 1993, 21.

121 Gindele 2013b; GINDELE 2014; Gindele 2015a.
} 
Tokaji-hegységtől keletre, a szatmári területeken feltárt települések, valamint a Kassa környéki lelőhelyek anyagában. Míg az előbbi területek kulturális fejlődését erősen befolyásolta Dacia provincia szomszédsága, ${ }^{122}$ addig a Hernád menti települések természetföldrajzi szempontból is zártabb tömböt alkottak. Ezeken a lelóhelyeken jóval tovább megfigyelhető az archaikus Przeworsk-kerámiatípusok (csőtalpas edények, tálkák, poharak, sütőtálak) használata: elóállításukhoz akkor is ragaszkodtak, mikor a jobb minőségú, gyorskorongolt edények a barbaricumi múhelyek megjelenésével könnyen beszerezhetơvé váltak. A Hernád-völgy és a Kassai-medence császárkori lakossága egy idáig nem azonosított helyi fazekasmúhelyből (vagy múhelyekből) szerezte be gyorskorongolt edényeit, melyek formái eltéréseket mutatnak a Szatmár környéki leletanyagtól. ${ }^{123}$

A Przeworsk anyagi kultúra összetett fejlődése mellett azonban olyan lelettípusok is megfigyelhetőek, melyek a szomszédos területek hatásáról árulkodnak. A magyarországi területeket a leletanyag alapján eltérő erősségú és jellegú kapcsolatok kötötték a szomszédos kulturális régiókhoz.

\section{A szarmata területek}

A szarmata kutatás számos alkalommal foglalkozott a germán-szarmata kapcsolatokkal, de fóként a temetkezésekból előkerült germán eredetú tárgyakat értékelték. ${ }^{124} \mathrm{Az}$ idegen eredetú, távolsági kapcsolatokat jelző leletek szarmata területen szinte kizárólag gazdagabban felszerelt sírokból kerültek elő, míg a települések leletanyagában csak elvétve találhatóak germán tárgytípusok. ${ }^{125}$ Eddigi adataink alapján a Przeworskés a szarmata települések élesen elkülönülnek a Felső-Tisza-vidéken, ${ }^{126}$ ami annak fényében figyelemre méltó, hogy a hasonló korú kvád és szarmata megtelepedés Aquincum elóterében például széles közös határsávot alkot. ${ }^{127} \mathrm{~A}$ Przeworsk-temetkezésekben sincs nyoma a szarmata elittel való kapcsolatnak, amit csak részben magyarázhat az, hogy a jellegzetes fegyveres síregyüttesekbe kevés viseleti elemet helyeztek.

\footnotetext{
122 GINDELE 2010.

123 JUREČKO 1983.

124 IstVÁNOVITS-Kulcsár 2017, 285-289, 293. Részben kereskedelmi kapcsolatként, részben a két népcsoport keveredésével magyarázva a leleteket.

125 Azok is inkább a kvád területekkel szomszédos szarmata telepekről (ISTVÁNOVITS-KuLCSÁR 2017, 294).

126 MASEK 2012, 255.

127 KULCSÁR 1997, 377.
}

A szarmata tárgyak hiánya a településeken még feltúnőbb: csak Garadna-Kovács-tanyán került elő egy csat, mely biztosan szarmata eredetú (4. kép 12). A hosszú ideig lakott Przeworsk települések kerámiaanyagában a Kr. u. 3. század során megjelenő félgömbös tálak nagy része helyi termék, a forma valószínúleg általános divat hatására terjedt el, ${ }^{128}$ csak néhány Garadna-Kovácstanyai darab esetén vethetó fel, hogy szarmata importokról van szó (9. kép 1-2). A szarmata eredet lehetősége ugyanennél a lelőhelynél néhány korongolt, finom anyagú hombár esetében is feltételes (9. kép 3), összességében azonban ezek száma elenyészó az összes leletet tekintve. ${ }^{129}$

\section{A kvád területek}

A Przeworsk-kerámiaanyagban, fóként az Eperjes-Tokaji-hegységtől nyugatra feltúnnek olyan edényformák és díszítésmódok, melyek a nyugat-szlovákiai településekre jellemzőek.

Egy alacsony, négyszögletes, négy sarkán egyegy kerek mélyedéssel ellátott edényke (wannenförmige Gefässe) került napvilágra Arkáról (9. kép 4), melynek legközelebbi analógiái Nyitra környékéről ismertek. ${ }^{130}$ Ugyaninnen származik egy finom, fényezett, kúpos, barbotindíszes pohár (9. kép 7), melynek díszítése nyugat-szlovákiai kvád telepeken gyakori, Magyarország területéról is kvád jellegú vagy nyugati kapcsolatokat mutató települések lelete. ${ }^{131}$ Durva anyagból ritkán, de készültek egyszerú, behúzott peremú, ívelt oldalú vagy kónikus tálak is, mint Hernádvécsén, Arkán és Garadnán (9. kép 5-6), ezek a formák a Sajótól nyugatra voltak igazán elterjedtek. ${ }^{132}$ Egy nagyméretú, finom, fényezett garadnai fazék formája szintén a kvád fazekakéra emlékeztet, ${ }^{133}$ de a vállon bemélyített három kör tipikus Przeworsk-díszítés (9. kép 9). ${ }^{134}$ Egy másik Garadna-Kovács-tanyai fazék függőleges becsipkedéssora szintén nyugat-szlovákiai edényeken gyakori, ${ }^{135}$ de maga a forma és a technológia nem tér el a helyi anyagtól (9. kép 8). Fontos még megemlíteni, hogy a korongolt, bepecsétléssel díszített edények egy része durva, szemcsés anyagú,

\footnotetext{
128 A Szamos-vidéken elterjedt félgömbös gyorskorongolt tálakat is inkább a provinciális múhelyekre, így a Drag. 37-es sigillata formára vezetik vissza (GINDELE-ISTVÁNOvITS 2009, Abb. 49).

${ }^{129}$ Csupán tucatnyi tárgyról lehet szó a több mint 15000 lelet közül.

130 Soós 2017, 29-30.

131 Soós 2017, 26.

132 SoÓs-TANKÓ 2018, 289.

133 VARSIK 2011, Abb. 30

134 Gindele-IstVÁNOVITS 2009, Abb. 35.

135 VARSIK 2011, Abb. 35, Abb. 39.
} 


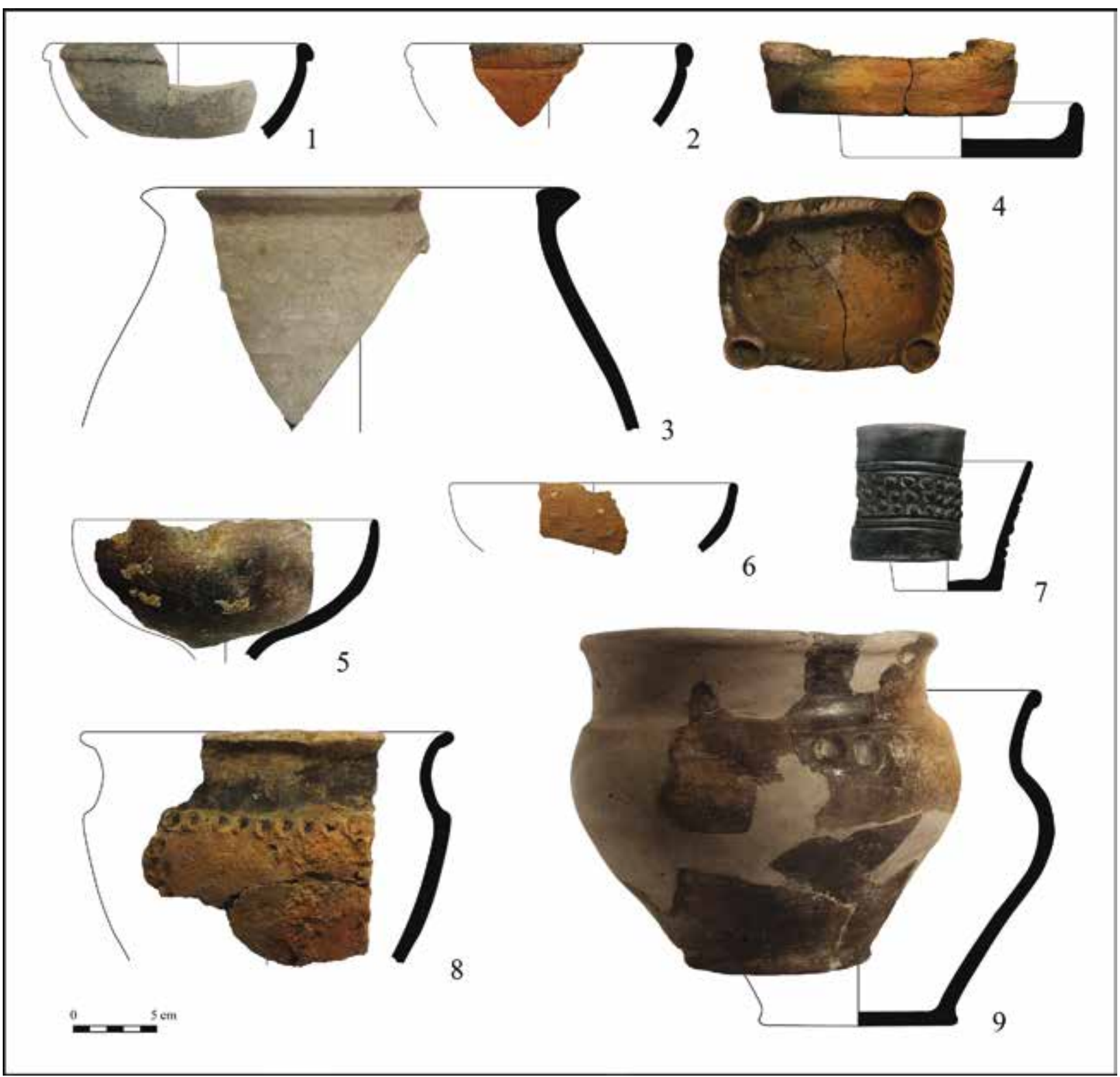

9. kép. Szarmata és kvád kapcsolatokra utaló leletek Przeworsk-településekről. 1-3., 5., 8-9. Garadna-Kovács-tanya; 4., 7. Arka-Fónyi-patak; 6. Hernádvécse-Nagy-rét

Fig. 9. Finds attesting to contact with the Sarmatians and Quads from Przeworsk settlements. 1-3., 5., 8-9. Garadna-Kovácstanya; 4., 7. Arka-Fónyi-patak; 6. Hernádvécse-Nagy-rét

a finomabb darabokon is feltúnnek nagyobb méretú, ovális, fogazott motívumok. Mindkét jelenség idegen a Beregsurány-típusú barbaricumi múhelyek termékeitôl, analógiáik viszont nyugati irányba mutatnak. ${ }^{136}$

A Przeworsk-településeken inkább kvád hatásról beszélhetünk, mintsem a két kultúrkör keveredéséról. A nyugati formát vagy díszítést mutató edények anyaga és kivitelezése nem tér el a települések helyben készült, kézzel formált anyagától. A kvád területek hatása az építészetre és bizonyos kistárgyakra (oldalt hajtott lábú fibulák és agancsfésúk elterjedésére), leginkább az Eperjes-Tokaji-hegységtől nyugatra érzékelhető.

\section{Provinciális kapcsolatok}

A Kárpát-medencei Przeworsk-területek Pannonia és Dacia provinciákkal való kapcsolata a leletanyag alapján nem tekinthető egységesnek. Kelet-Szlovákia, azon belül is fóként a Kassaimedence császárkori településein jóval magasabb arányban kerültek eló római tárgyak, mint 136 Soós in press. 
Dacia északnyugati peremvidékén. ${ }^{137}$ A Hernád és a Tarca (Torysa) völgyében feltûnő nagyszámú import alátámasztja azt a megállapítást, hogy itt futhatott Aquincum térségéból a Kárpátok északkeleti hágói felé a kereskedelmi út. ${ }^{138}$

A Kárpát-medencei kvád, szarmata és Przeworsk-területek között abban is némi eltérés figyelhető meg, hogy mely terra sigillata-gyártó múhely termékei kerülnek elő gyakrabban. A Magyarország területén feltárt kvád települések leletanyagában eddigi ismereteink alapján a rheinzaberni múhely termékei domináltak, a késői pfaffenhofeni darabokat kevesebb töredék képviselte. ${ }^{139}$ Szarmata területen erős regionális eltérések figyelhetőek meg, egyes lelőhelyeken a rheinzaberni múhely termékei kerültek elő magasabb számban, ${ }^{140}$ de sok helyen a westerndorfi dominál. ${ }^{141}$ Mivel a különböző múhelytermékek aránya a lelőhelyek feltárásának és feldolgozásának ütemében is változik, az információk messzemenó következtetések levonását nem teszik lehetővé. ${ }^{142}$

A különböző múhelytermékek barbaricumi használatának kronológiai bizonytalansága miatt a római importban megfigyelhetó eltéréseket jobban kifejezik a különböző kerámiatípusok. A szarmata területen megtalálható, mintásan vörösre festett, a bepecsételt kerámia és amfora eddig nem ismert a Felső-Tisza-vidékről.143 A Hernád mentén viszont jelentôs számú, félgömbös, szürke agyagbevonatos tál töredéke került elő. A típus nemcsak a szarmata területekról hiányzik, hanem a Przeworsk-régióban is, csak Miskolc környékén ${ }^{144}$ és a Kassai-medencében ${ }^{145}$ figyelhető meg súrúsödésük. Utóbbi területtel a Garadna-Kovács-tanyai település leletanyaga egyébként is szoros rokonságot mutat, a szürke

137 GINDELE 2010, 146, 491. Jegyzet, 8 lelőhelyről csupán 15 terra sigillata töredéket ismertetett, ellentétben: KuZMOVÁ 2014, Map. 1.

138 VADAY 1998; ARDELEANU 2014, 19-20.

139 Vác-Csörögi rétek (KulCSÁr-HoRVÁth 2002, 313, Tab. 1).

140 Gyoma-133. lh. (GABLER-VADAY 1992, Abb. 19); DunakesziAlagi major (GABLER 2001), az összefoglaló gyújtés is a rheinzaberni termékek dominanciáját mutatta (GABLERVADAY 1992, 133).

${ }^{141}$ Nagyút-Göböly-járás II (HoRvátH 2009); Felgyő-Kettőshalmi dúlő (SósKUTI-WilHelm 2014).

142 Kelet-Szlovákia területén M. Ardeleanu a rehinzaberni és a westerndorfi termékek kiegyensúlyozott arányát figyelte meg (ARDELEANu 2014, 15), K. Kuzmová az újabb feldolgozott töredékekkel a rehinzaberni darabok túlsúlyát (KuZMOvÁ 2014, 173).

143 SÓSKUTI-WILHELM 2014, 71.

144 Miskolc-Szabadság tér (VÉGH 1964, 49, II. т. 18-19); MiskolcSzirma (VÉGH 1989, 7. kép 26, 22. kép 4); SzimabesenyőHomokbánya (VÉGH 1999, 211-212); SajókeresztúrHomokbánya (VÉGH 1985, 103).

145 Peder/Péder (LamiovÁ-Schmiedlová 1969, 420, Abb 14); Trstené pri Hornáde/ Abaújnádasd (JUREČKO 1983, Obr. 40, 3). mázas áru megjelenése utalhat Pannóniával való hasonló vagy közös kapcsolatra.

A Hernád-völgyi települések, elsősorban Garadna-Kovács-tanya kerámiaanyagának részletes kiértékelése alapján megállapítható, hogy a készítő múhelyekkel szemben a római edényeknek a formatípusa volt a meghatározó a barbár környezetben. A kisméretú edények, a Drag. 33-as csészék és a Drag. 52/54-es csuprok akkor fordultak elő a településen, ameddig a helyben készült, kisméretú edények egyébként is a háztartási készlet részét képezték. A kerámiaspektrum átalakulásával ezek eltúntek, a finom kerámia nagy részét tálak tették ki, melyeket a település lakói Drag. 37-es sigillata formákkal egészítettek ki. ${ }^{146}$

\section{Gazdálkodás és településszerkezet}

A Hernád, a Tisza és a Bodrog menti folyóteraszokon letelepült életmódot folytató, földmúvelésből és állattartásból élő, önellátó közösségek telepedtek meg, akik regionális kapcsolatokat tartottak fent a környező területekkel.

Az egykori települések életmódjára csak nagy vonalakban lehet következtetni. A gabonafélék őrlésére használt kézi malomkőtöredékek, a szemes termény tárolására szolgáló hombárok magas száma is a földmúvelés kiemelkedő szerepére utal. A tárgytípusok szinte minden Przeworsk-telepen megtalálhatóak, ennek ellenére a gazdálkodás módjára, a termesztett növényfajokra és azok hasznosítására alig van adatunk. A települések nagyrészt konyhahulladékból származó állatcsontanyaga alapján az étkezésben szinte kizárólag a háziasított fajok, elsősorban a szarvasmarha játszott szerepet, a vadászott állatok húsa elhanyagolható volt. A szarvasmarha mellett a sertéshús fogyasztása állt a második helyen. ${ }^{147}$ Érdekes, hogy a ma is erdővel borított, gazdag vadállományú Zemplén közelsége menynyire nem befolyásolta a húsfogyasztási szokásokat, annak ellenére, hogy vadászatra utaló adattal több lelőhelyről rendelkezünk.

146 Valószínú, hogy a szarmata és germán területek római importjában megfigyelhető formai eltérések is a két népcsoport által használt étkészlet különbségében kereshetőek. Szarmata területen jóval magasabb arányban található meg a Drag. 33-as forma, melynek ürtartalma feltehetően jobban idomult a kis méretben is készült szarmata edényekéhez. Przeworsk-területen ezzel szemben a helyi készletben vagy kisebb poharak, tálkák, vagy nagyobb tálak találhatóak, melyek úrtartalmához a Drag. 54. és a Drag. 37. formák illeszkednek. A jelenségre már többen felhívták a figyelmet (GABLER-VADAY 1992, 91; KUZMOVÁ 2014, 178).

147 DARÓCZI-SZABÓ 2009; VÖRÖS-SOÓs 2014. 
A települések szerkezete és a térhasználat

A nagyobb felületeken feltárt lelőhelyek, Hernádvécse-Nagy-rét és Garadna-Kovács-tanya selejtezetlen leletanyaga lelehetőséget adott az adatbázisban rögzített adatok többváltozós ma- tematikai statisztikai elemzésére is. A vizsgálat egyik fő kérdése a térhasználatra vonatkozott, miszerint el lehet-e különíteni a leletanyag (háztartási hulladék) szóródása alapján eltéró hasznosítású területeket vagy jelenségtípusokat az egyes településeken. A modellhez a leletanyag a

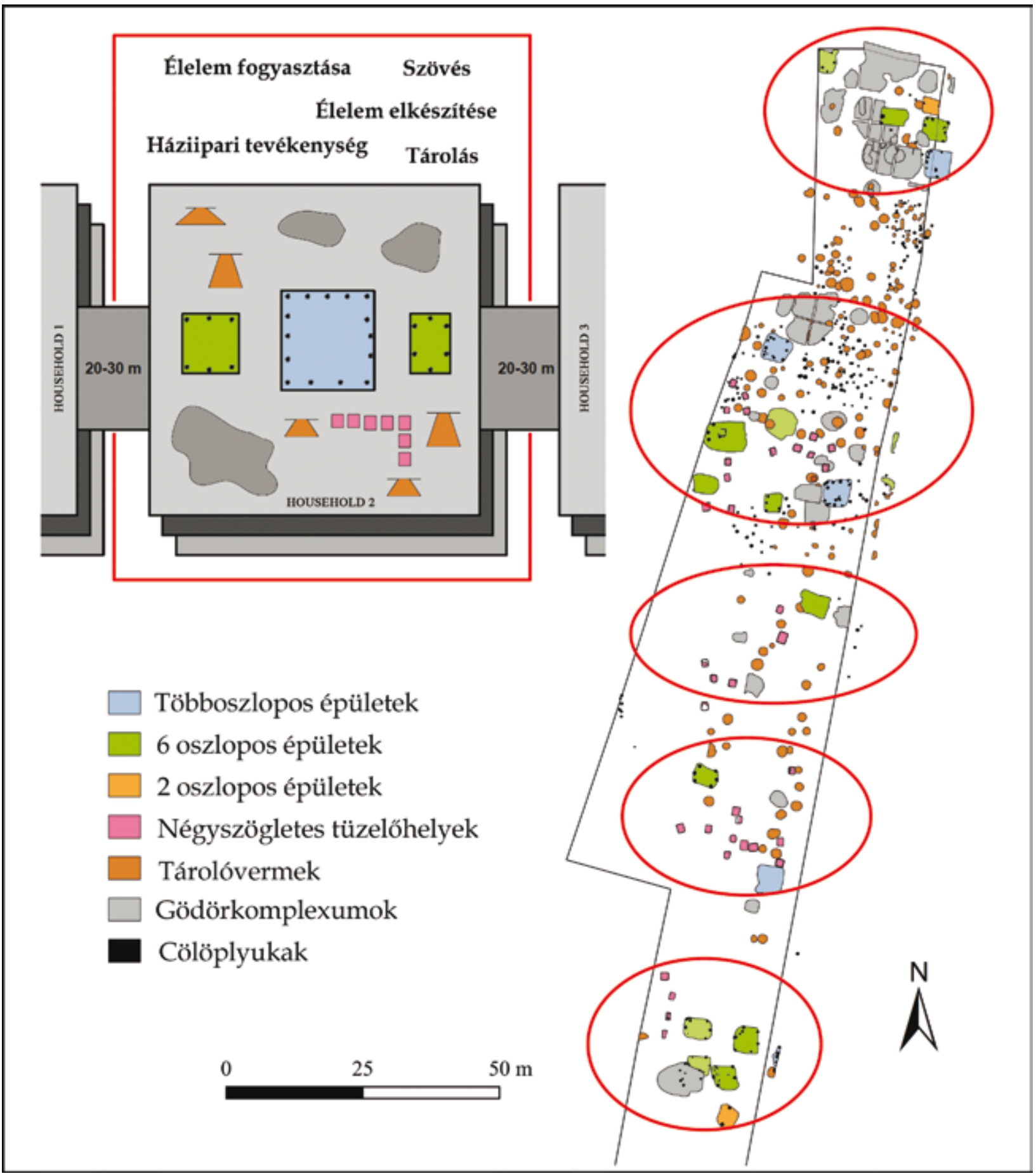

10. kép. A térhasználat Garadna-Kovács-tanya lelőhelyen

Fig. 10. Occupation patterns at Garadna-Kovács-tanya 
háztartásban betöltött funkció alapján került csoportosításra. ${ }^{148}$

Az eredmények alapján a két település az anyagi kultúra említett különbségei mellett a térhasználatban is mutatott eltéréseket.

A Garadna-Kovács-tanyai településen az egy idóben múködő gazdasági egységek vagy háztartások egységes képet mutattak. Az egymástól 15-20-30 m-re létesített egységek mindegyike egy sokcölöpös és két-három hatoszlopos szerkezetű épületből, két-három kisebb és egy nagyméretú, hulladékkal feltöltődött agyagnyerő helyből állt. Szigorúan az épületek határolta tereken belül kerültek elő a négyszögletes tüzelőhelyek, háztartás-csoportonként 4-20 jelenség. A hengeres, méhkas és ívelt kialakítású tárolóvermek ilyen szigorú rendszert nem mutattak, a jelenségcsoportok közt is előfordultak.

A funkcionális vizsgálat alapján ez a szigorúan meghatározott, 30-35 m-es terület szolgált a különböző háztartási munkák helyszínéül. Az élelem elkészítése, fózése (esetleg kis mennyiségben való tárolása) és elfogyasztása mellett a textilkészítés is ugyanazon a helyen történhetett. Az élelem tárolásának, előkészítésének területe nem vált el élesen a bőrfeldolgozás és egyéb, nehezebben körvonalazható háziipari tevékenységek helyszínétől. Az étkezésból származó állatcsonthulladékot ismét máshol, de inkább az utóbbi munkálatok helyszínének közelében dobták ki. A háztartási tevékenységek a leletanyag szóródása alapján az épületcsoportok által meghatározott zónában zajlottak. A különböző cselekvések összefüggését bizonyos jelenségtípusokkal nem lehetett kimutatni, tehát a különböző cselekvéseket nem lehetett meghatározott épületszerkezetekhez kapcsolni (10. kép).

A háztartásokat ugyanazon a zónán belül újították meg. Az épületek, agyagnyerő gödrök és a négyzetes tüzelőhelyek is sorban, egymáshoz közel, helyenként egymásra ásva kerültek elő, ami folyamatos térhasználatra utal.

Hernádvécse-Nagy-rét lelőhelyen eltérő jellegú települést tártak fel. A szórt szerkezetú háztartási egységek szintén a Bársonyos-patak mentén helyezkedtek el, de 180-200 m-re egymástól. A kiterjedt, 100-120 m-es területen elterülő háztartás központját valószínúleg egy nagyobb alapterületú, cölöpszerkezetes felszíni építmény és

\footnotetext{
148 A vizsgálatról és a módszertanról részletesen: Soós 2015; Soós 2016. és Soós Eszter: Nagy felületen kutatott horizontális települések elemzése statisztikai és térinformatikai módszerrel. Esettanulmány a 3-as sz. foút mentén elókerült Przeworsk (Kr. u. 2-4. század) telepek alapján (konferenciaelőadás.) Elhangzott: Innovatív térinformatikai fejlesztések és lehetőségek a régészetben. Lakitelek 2016. október 13-14.
}

egy hatoszlopos, földbe mélyített épület jelentette, ezektől 40 m-re, északra és délre helyezkedett el egy-egy nagyobb és két-két kisebb, hulladékkal feltöltődött agyagnyerő gödör. Ugyanilyen távolságra ásták le a négyzetes tüzelóhelyeket, szintén É-D-i sorokban, de egy csoportban, elkülönülve az egyéb jelenségektől. Az agyagnyerő gödröktől további 30-40 m-re, egy kisebb, oszlophely nélküli vagy kétoszlopos épület és körülötte tárolóvermek egészítették ki a háztartási egységet.

A funkcionális elemzés alapján Hernádvécsén a különböző háztartási tevékenységeket eltérő helyen végezték. Az élelem elkészítése, elfogyasztása és a textilmúvesség szintén összefüggést mutat, itt azonban ezek a földfelszíni és a hatoszlopos épületekben zajlottak. Az épületek hulladékát a tőlük 35-40 m-re leásott agyagnyerő gödrökbe dobták. A kétoszlopos, kisebb épületek leletanyaguk alapján az élelem-előkészítés és esetleg egyéb ipari tevékenység helyszíneként szolgáltak, a környezetükben feltárt vermeket pedig tárolásra használták (11. kép).

Hernádvécsén tehát tevékenységek szerint elkülönülő térhasználattal számolhatunk. A háztartásokat viszont, Garadna-Kovács-tanyához hasonlóan, ugyanazon a zónán belül újították meg, határuk tehát idővel nem módosult.

\section{Összegzés}

A tanulmány a római császárkori Przeworskkultúra Magyarország területén feltárt településeinek legújabb kutatási eredményeit foglalta össze.

A lengyelországi törzsterülettel rendelkező Przeworsk-kultúra a Kárpát-medencében a markomann háborúk korában és az azt követő évtizedekben érte el legnagyobb kiterjedését: délkeleti irányban a daciai limes, dél felé az alföldi szarmata területek felé élesen lehatárolható a kiterjedése, míg nyugatra, a kvád településterület irányába a határ pontosan egyelőre nem rajzolható meg. A gyér számú, hamvasztásos sírmaradvánnyal szemben, melyek nagy része a Kr. u. 2. század második fele és a 3. század első fele közé keltezhető, a településeken az élet a késő császárkorban is követhető, egyes lelőhelyek a Kr. u. 4. század utolsó harmadát is megérték.

A mezőgazdaságból élő településeket földbe mélyített, a germán Barbaricumra jellemző oszlopszerkezetes épületek, tárolóvermek, nagyméretú, hulladékkal feltöltött gödörkomplexumok és négyszögletes, nem meghatározható funkciójú tüzelőhelyek alkották, melyek települési egysé- 


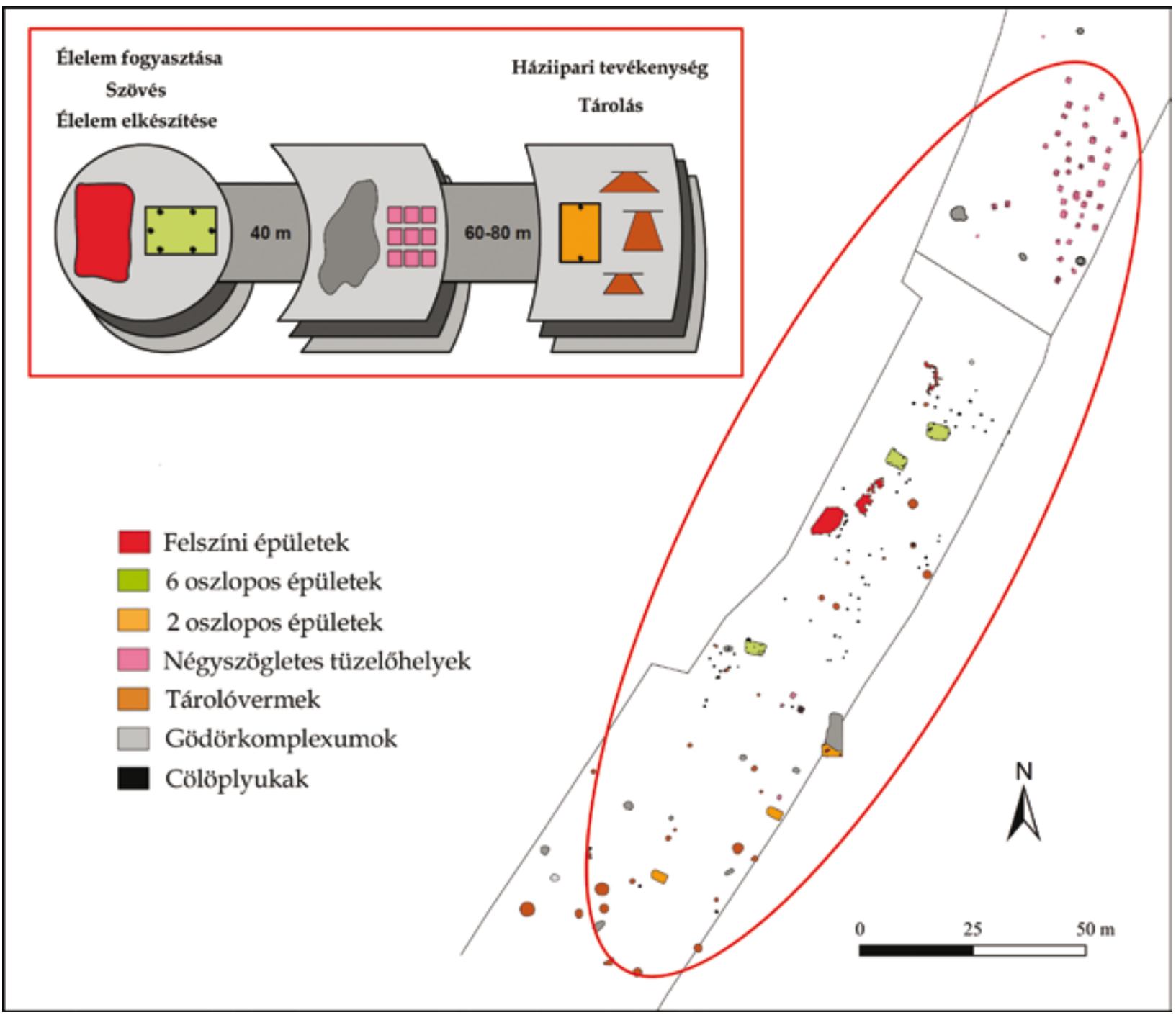

11. kép. A térhasználat Hernádvécse-Nagy-rét, 4-5. lelőhelyeken

Fig. 11. Occupation patterns at Hernádvécse-Nagy-rét, Sites 4-5

geket alkotva, sorban helyezkedtek el vízfolyások mentén. Leletanyagukban a germán hagyományú, kézzel formált, fekete, fényezett, finom, fogyasztási vagy díszítési célú edényeket és a durva, kézzel formált főzőedényeket már a Kr. u. 2. század második felétől-végétől fazekasmúhelyekben előállított, gyorskorongolt áruval egészítették ki. Tárolás céljára nagyméretú hombárok szolgáltak.
A leletanyag alapján a Przeworsk-településeken élők elsősorban Pannonia provincia felé tartottak fent kereskedelmi vagy cserekapcsolatokat. A szomszédos szarmata és kvád területek anyagi kultúrájának hatása nem annyira import tárgyakon, hanem a kerámiamúvességben bizonyos formai és díszítési jegyek megjelenésében figyelhető meg. 


\section{IRODALOM}

Almássy, KATALIN

2001 New data on the Celto-Dacian relationship in the Upper Tisza Region. In: Istvánovits, E.-Kulcsár, V. (eds): International Connections of the Barbarians of the Carpathian Basin in the $1^{\text {st }}-5^{\text {th }}$ centuries A.D., Aszód-Nyíregyháza, 45-55.

2009 Celts and Dacians (?) in the Great Hungarian Plain:1 $1^{\text {st }}$ c. BC $-1^{\text {st }}$ c. AD. In: Salač, V.-Bemmann, J. (Hrsg.): Mitteleuropa zur Zeit Marbods. Tagung Roztoky u Křivoklatu 4.-8. 12- 2006. Anlässlich des 2000 jährigen Jubiläums des römischen Feldzuges gegen Marbod. Praha-Bonn, 251-268.

ARDELEANU, MARIUS

2014 Imports of terra sigillata in the Upper Tisza Basin. Statistic view and historical remarks. Anodos. Studies of the Ancient World. Trnava, 11/2011 9-20.

BARKÓCZI, LÁSZLÓ

1988 Pannonische Glasfunde in Ungarn. Studia Archaeologica (Budapest) 9.

BENINGER, EDUARD

1937 Die germanischen Bodenfunde in der Slowakei. Leipzig.

BÓNA ISTVÁN

1986 Szabolcs-Szatmár megye régészeti emlékei I. In: Németh P. (szerk.): Szabolcs-Szatmár megye múemlékei. Budapest, 15-91.

1993 A honfoglalás előtti kultúrák és népek. In: Cservenyák L. (szerk.): Szabolcs-Szatmár-Bereg megye monográfiája. I. Nyíregyháza, 63-137.

BÓNIS ÉVA

1970 A brigetiói sávos kerámia (Die streifenverzierte Keramik aus Brigetio). Folia Archaeologica (Budapest) 21, 71-90.

BudinSKÝ-KRIČKA, VoJTECH-LAMIOVÁ-SCHMiEdLOVÁ, MÁRIA

1990 A late $1^{\text {st }}$ century B.C.-2nd century A. D. cemetery at Zemplín. Slovenská archeológia (Bratislava) 38, 245-344.

COÇIŞ, SORIN

2004 Fibulele din Dacia Romană. The Brooches from Roman Dacia. Bibliotheca Ephemeris Napocensis (Cluj-Napoca) 3.

COCIŞ, SORIN-BÂRCA, VITALIE

2014 The "Sarmatian" brooches (headknob and full catchplate variant, Almgren Group VII, Series I) in the Dacia province and the Barbarian environment of the Tisza River Basin. Dacia. Revue d'archéologie et d'histoire ancienne (București) 58, 189-214.

COTTAM, SALlY-PRICE, JENNIFER

1998 Romano-British glass vessels: A handbook. York.

CSENGERI PIROSKA

2015 Középső neolitikus telepnyomok Mezőzombor-Községi temető lelóhelyről (Middle Neolithic settlement remains from Mezőzombor-Községi temető [North-eastern Hungary]). A Herman Ottó Múzeum Évkönyve (Miskolc) 54, 39-78.

CSEngeri Piroska-Pusztai Tamás

2008 Császárkori germán település a Hernád völgyében (Előzetes jelentés a Garadna-elkerülő út, 1. lelőhelyen végzett feltárásról) [Germanic (Vandal) settlement of the Roman Period from the Hernád Valley (Northeastern Hungary). Preliminary report on the excavation at Garadna-elkerülő út, site No. 1]. A Herman Ottó Múzeum Évkönyve (Miskolc) 47, 89-106.

DARÓCZI-SZABó MÁrTA

2009 Garadna-Elkerülő út 1. lelőhely (Garadna-Kovács tanya) germán állatcsontjainak vizsgálata [Analisys of German animal remains from Garadna-Elkerülö út 1. Site (Garadna-Kovács tanya)]. A Herman Ottó

DÉVAI KATALIN Múzeum Évkönyve (Miskolc) 48, 335-355.

2012 Késő római temetkezések üvegmellékletei Pannoniában. Üvegedények a mai Magyarország területéról I. Doktori disszertáció. ELTE BTK Budapest.

2013 Terminológiai alapfogalmak régészeti korú üvegtárgyak elemzéséhez. Dissertationes Archaeologicae (Budapest) 3/1, 85-112.

DINNYÉS ISTVÁN

1991 A hévízgyörki szarmata sírok. (Sarmatian graves from Hévízgyörk). Studia Comitatensia (Szentendre) $22,145-201$.

DROBERJAR, EDUARD

1997 Studien zu den germanischen Siedlungen der älteren römischen Kaiserzeit in Mähren. Praha.

2012 Ř́mské kolínkovité spony v Čechách. Römische Kniefibeln in Böhmen. (Archeologické výzkumy v jižních Čechách 25) České Budějovice, 119-131. 
GABLER DÉNES

1968 Terra sigillaták a Kelet-Pannóniával szomszédos Barbaricumban. A Barbaricum importjának néhány kérdése. Archaeologiai Értesítő (Budapest) 95, 211-242.

2001 Terra sigillata-Funde aus der sarmatischen Siedlung Dunakeszi-Alagi major. Slovenská archeológia (Bratislava) 19, 119-138.

GABLER DÉNES-VADAy ANDREA

1992 Terra Sigillata im Barbaricum zwischen Pannonien und Dacien, II. Teil. Acta Archaeologica Academiae Scientiarum Hungaricae (Budapest) 44, 83-160.

GINDELE, ROBERT

2004 Probleme privind ceramica dacică şi germanică din aşezările din nord-vestul României. Satu MareStudii şi Comunicări 17-21, 2000-2004, 71-88.

2010 Die Entwicklung der kaiserzeitlichen Siedlungen im Barbaricum im nordwestlichen Gebiet Rumäniens. Satu Mare.

2013a Die Problematik der barbarischen Siedlungen im Nordwesten Rumäniens zwischen der Gründung der Provinz Dakien und den Markomannenkriegen. Ephemeris Napocensis (Cluj-Napoca) 23, 11-30.

2013b Neue Forschungen zur römerzeitlichen Keramikherstellung im Barbaricum- das Zentrum von Medieşu Aurit-Şuculeu. Ein kurzer Vorbericht. In: Keramikherstellung in Osteuropa: Spätrömische Zeit Frühmittelalter - Neuzeit. Materialen des Feldseminars an der Basis der Expedition bei Vojtenki, 17.-19. September 2012. (Ostrogothica Heft 2.) Charkov, 95-105.

2014 Die Siedlung in Moftinu Mic - Merli tag. Probleme im zusammenhang mit den Markomannenkriegen in den Siedlungen im Nordwesten Rumäniens. In: Cociş, S. (Hrsg.): Archäologische Beiträge. Gedenkschrift zum hundertsten Geburtstag von Kurt Horedt. Patrimonium Archaeologicum Transylvanicum, Volume 7. Cluj-Napoca, 139-152.

2015 Roman Period Barbarian settlements in Partium (Northwestern Romania). Hungarian Archaeology online (2015) Spring.

2015b Die römerzeitlichen Barbarensiedlungen von Livada/Ciuperceni- PV-Anlage GPSP Solaris und Supuru de Sus-Togul lui Cosmi. Neue Angaben bezüglich der rechteckigen Gruben mit gebrannten Wänden aus dem 2. - 5. n. Chr. im oberen Theiß-Becken. Dacia. Revue d'archéologie et d'histoire ancienne (București) $59,83-126$.

GINDELE, ROBERT-ISTVÁNOVITS, ESZTER

2009 Die römerzeitliche Siedlung von Csengersima-Petea. Satu Mare.

2011 Die römerzeitlichen Töpferöfen von Csengersima-Petea. Satu Mare.

GODŁOWSKI, KAZIMIERZ

1984 "Superiores Barbari“ und die Markomannenkriege im Lichte archäologischer Quellen. Slovenská archeológia (Bratislava) 32/2, 327-346.

1992 Die Chronologie der jüngeren und späten Kaiserzeit in den Gebieten südlich der Sudeten und Karpaten. In: Godłowski, K.-Madyda-Legutko, R. (Hrsg.): Probleme der Relativen und Absoluten Chronologie ab LaténeZeit bis zum Frühmittellter. Materialen des III. Symposium. Grundproblemeder Frühgeschichtliche Entwicklungen im nördlichen Mitteldonaugebiet. Krakow - Karniowice 3.-7. dezember 1990. Kraków, 23-54.

1993 Die Barbaren nördlich der Westkarpaten und das Karpatenbecken-Einwanderungen, politische und militäriche Kontakte, Specimina Nova 9/1, 65-89.

GroH, Stefan-SEDLMAYER, Helga

2002 Forschungen im Kastell Mautern-Favianis. Die Grabungen der Jahre 1996 und 1997. Der römische Limes in Österreich (Wien) 42.

GYALAI ZsÓFIA

2009 Garadna-Elkerülő út, 1. lelőhely Terra sigillata leletanyaga. A Herman Ottó Múzeum Évkönyve (Miskolc) 48, 357-366.

2012 Borsod-Abaúj-Zemplén megye terra sigillata leletei. A terület etnikai viszonyai és kereskedelmi kapcsolatai a római luxuskerámia tükrében. Szakdolgozat. Szegedi Tudományegyetem, Szeged.

HORVÁTH FRIDERIKA

2009 Nagyút-Göböly-járás II. A terra sigillata anyag időrendje a szarmata telepen. Nagyút-Göböly-járás II. Die Chronologie der terra sigillaten in der sarmatischen Siedlung. In: Szabó A. (szerk.): Ripam Omnem Quaesivit. Pécs-Paks, 101-126.

HulLÁM DÉNES

2012 A Przeworsk-kultúra hamvasztásos temetkezéseinek időrendi vizsgálata a Kárpát-medence északkeleti részén. In: Petkes Zs. (szerk.): Hadak Útján XX. A Népvándorláskor Fiatal kutatóinakXX. Összejövetelének konferencia-kötete. Budapest-Szigethalom 2010. október 28-30. Budapest, 83-97.

ISINGS, CLASINA

1957 Roman glass from dated finds. Archaeologica Traiectina II, Edita ab Academiae Rheno-Traiectinae Institutio Archaeologico. Groningen-Djakarta. 
ISTVÁNOVITS ESZTER

1990 A Felső-Tisza-vidék legkorábbi szarmata leletei. 2-3. századi sírok Tiszavasváriból. A Jósa András Múzeum Évkönyve (Nyíregyháza) 27-29, 1984-1986, 83-133.

1993 Az apagyi császárkori telep. A Jósa András Múzeum Évkönyve (Nyíregyháza) 33-35 (1990-1992) 9-33.

1997 Some data on the ethnical and chronologlcal determination of the Roman Age population of the Upper Tisza Region. Acta Musei Porolissensis (Zalău) 21, 717-742.

ISTVÁNOVITS EsZTER-KuLCSÁR, VALÉRIA

2002 Csat a szarmata viseletben és a temetkezési rítusban (Buckles in the Sarmatian costume and burial rite). A Jósa András Múzeum Évkönyve (Nyíregyháza) 44, 95-112.

2006 Az első szarmaták az Alföldön. (Gondolatok a Kárpát-medencei jazig foglalásról) [The first Sarmatians in the Great Hungarian Plain. (Some notes on the Jazygian immigration into the Carpathian Basin)]. A Jósa András Múzeum Évkönyve (Nyíregyháza) 48, 203-236.

2017 Sarmatians. History and Archaeology of a forgotten People. Monographien des RGZM Band 123.

2018 „...Aligha állhat nekik bármely csatarend ellent.” Egy elfelejtett nép, a szarmaták. Nyíregyháza-Szeged, 2018.

JUREČKO, PAVEL

1983 Prispevok k riešeniu problematiky osídlenia východného Slovenska v dobe rímskej. Historia Carpatica. Zborník Východoslovenského múzea v Košiciach (Košice) 14, 277-384.

KACZANOWSKI, PIOTR

1995 Klasyfikacja grotów broni drzewcowej kultury przeworskiej z okresu rzymskiego. Klasyfikacje Zabytków Archeologicznych I. Kraków.

KAMINSKÁ, L'UBOMÍRA

2005 Dve fázy Osídlenia z doby rímskej v Čičarovciach. Zwe Besiedlungsphasen aus der römischen Kaiserzeit in Čičarovce. Východoslovenský pravek (Košice) 7, 57-82.

KELEMEN MÁRTA

1980 Római kori fazekaskemencék Balatonfúzfön (Töpferöfen aus der Römerzeit in Balatonfúzfö). Veszprém Megyei Múzeumok Közleményei (Veszprém) 15, 49-72.

KoBÁLY JÓZSEF

1998 A Przeworsk kultúrához tartozó harcossírok és fegyverleletek Kárpátalján (Römerzeitliche Waffenbestattungen in der Karpatoukraine und die Barbarenangriffe auf den Limes). A Jósa András Múzeum Évkönyve (Nyíregyháza) 39-40, 113-134.

KOLNÍK, TITUS

1962 Nové sídliskové nálezy z doby rímskej na Slovensku. Archeologické rozhledy (Praha) 14, 344-386, 371-380, 385-397.

1998 Haus und Hof im quadischen Limesvorland. In: Leube, A. (Hrsg.): Haus und Hof im östlichen Germanien. Bonn, 144-159.

KOLNík, Titus-VARSIK, VladimiR-VladÁR, JAN

2007 Branč. Germánska osada z 2. až 4. storočia. Eine germanische Siedlung vom 2. bis zum 4. Jahrhundert. ASM Catalogi X. Nitra.

KONTNY, BARTOSZ

2008 The war as seen by an archaeologist. Reconstruction of barbarian weapons and fighting techniques in the Roman Period basen on the analysis of graves containing weapons. The case of the Przeworsk culture. Journal of Roman Military Equipment Studies 16, 107-145.

KOTIGOROSKO, VYACHESLAV

1995 Tinuturile Tisei Superioare in veacurile III. i.e.n. - IV. i.e.n. (Perioadele La Tène şi romană). Biblioteca Thracologica XI. Bucureşti.

2009 Mala Kopanya. Mala Kopania. Micromonografie. Kismonográfia. Korotka Monografiia. MiniMonograph. Satu Mare.

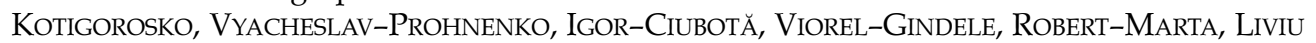

2004 Necropola aşezării fortificate de la Malaia Kopania. The Necropolis of Malaia Kopania Fortified Settlement. In: Studii şi Comunicări Satu Mare, 17-21/I, 59-70.

KOVRIG, ILONA

1937 Die Haupttypen der kaiserzeitlichen Fibeln in Pannonien. Budapest.

KREKOVIČ, EDUARD

1992 Zur Datierung der Fürstengräber der römischen Kaiserzeit in der Slowakei. In: Probleme der relativen und absoluten Chronologie ab Laténezeit bis zum Frühmittelalter. Krakow, 55-68.

KULCSÁR VALÉRIA

1997 Császárkori telepásatások a 2. számú főút nyomvonalában. (Előzetes jelentés). Pest Megyei Múzeumi Füzetek 4, 374-377.

2004 Germanic settlement of Imperial Age near Vác. Študijné zvesti Archeologického ústavu Slovenskej akadémie vied (Nitra) 36, 229-241. 
KulCSÁR, VALÉRIA-HORVÁTH, FrIDERIKA

2002 Die Terra Sigillata Funde der kaiserzeitlichen Siedlung Vác-Csörögi-rét im Barbaricum. In: Rajtár, J.Pieta, K.-Kuzmová, K. (eds): Zwischen Rom und dem Barbaricum. Festschrift für Titus Kolník zum 70. Geburtstag. Nitra, 313-324.

KuZMOVÁ, KLÁRA

2014 Roman Pottery in Barbaricum: the case of terra sigillata in north-eastern part of the Carpathian Basin (Eastern Slovakia). Anodos. Studies of the Ancient World. Trnava, 11/2011, 171-184.

KuZMOVÁ, KLÁRA-RÁKOS, JÁN

2016 Roman provincial products from the native settlement of the Przeworsk culture at Trstené pri Hornáde (Eastern Slovakia). Anodos. Studies of the Ancient World. Trnava, 12/2012, 163-172.

LAMIOVÁ-SCHMIEDLOVÁ, MARIA

1969 Römerzeitliche Siedlungskeramik in der Südostslowakei. Slovenská Archeológia (Bratislava) 17/2, 403-502.

1992 Chronologie der römischen Kaiserzeit in der Ostslowakei. In: Godłowski, K.-Madyda-Legutko, R. (Hrsg.): Probleme der Relativen und Absoluten Chronologie ab Laténe zeit bis zum Frühmittellter. Materialen des III. Symposium. Grundprobleme der Frühgeschichtliche Entwicklungen im nördlichen Mitteldonaugebiet. Krakow - Karniowice 3.-7. dezember 1990. Kraków, 75-80.

LEUBE, ACHIM

2009 Studien zur Wirtschaft und Siedlung bei den germanischen Stämmen im nördlichen Mitteleuropa während des 1. bis 5/6. Jh n. Chr. Römisch-Germanischen Forschungen Band 64. Mainz am Rhein.

LUŠTIKOVÁ, LUCIA

2007 Dácka Keramika na území Slovenska. Dacian Ceramics in Slovakia. Východoslovenský Pravek 8, 77-95.

2013 Šebastovce-Barca, keramika doby rímskej. Šebastovce-Barca, Keramik der Römerzeit. Študijné zvesti archeologického ústavu Slovenskej akadémie vied (Nitra) 54, 91-110.

MĄCZYŃSKA, MAGDALENA

2001 Einige Fibeln südlicher Herkunft im Hortfund von Łubiana in Pommern. In: Istvánovits, E.-Kulcsár, V. (eds): International Connections of the Barbarians of the Carpathian Basin in the $1^{\text {st }}-5^{\text {th }}$ centuries A.D. Proceedings of the international conference held in 1999 in Aszód and Nyíregyháza, Aszód-Nyíregyháza, 77-93.

MADYDA-LegutKo, ReNATA-RODZIŃKA-NOWAK, JUdYTA

2012 Interkulturelle Beziehungen der Bevölkerung der Przeworsk-Kultur in der Karpatenzone am Übergang von der frühen zu der jüngeren römischen Kaiserzeit am Beispiel des Gräberfeldes von Prusiek, Fst. 25, Gde. Sanok. Interkulturní vztahy lidu Przeworské Kultury v Karpatské oblasti na přelomu starší a mladší doby rímské na př́kladu pohřebiště v Prusieku, lok. 25, obec Sanok. Přehled výzkumů (Brno) $53 / 1,75-87$.

MADYDA-LEGUtKo, ReNATA-RodZiŃSKA-NOWAK, JUdYTA-ZAGÓRSKA-TELEGA, JOANNA

2013 New data concerning the cultural situation in the basin of the Upper San River during the Roman Period (Új adatok a Felső-San-vidék római kori kulturális helyzetéhez). A Jósa András Múzeum Évkönyve (Nyíregyháza) 55, 409-422.

MASEK ZsÓFIA

2012 Római császárkori települések Kántorjánosi és Pócspetri határában. Kaiserzeitliche Siedlungen in den Gemarkungen von Kántorjánosi und Pócspetri. In: Szabó, Á.-Masek Zs. (szerk.): Ante viam stratam. A Magyar Nemzeti Múzeum megelőző feltárásai Kántorjánosi és Pócspetri határában az M3 autópálya nyírségi nyomvonalán. Budapest, 179-342.

2016 The transformation of Late Antique comb types on the frontierof the Roman and Germanic world Early medieval antler combs from Rákóczifalva (County Jász-Nagykun-Szolnok, Hungary). Antaeus. Communicationes ex Instituto Archaeologico Academiae Scientiarum (Budapest) 34, 105-172.

MERCZI MÓNIKA

2011 Térdfibulák Komárom-Esztergom megyéből. A Komárom-Esztergom Megyei Múzeumok Közleményei 17, 7-80.

2012 A Budaörs-Kamaraerdei dúlőben feltárt római vicus fibulái. In: Ottományi K. (szerk.): Római vicus Budaörsön. Budapest, 473-528.

OLĘDZKI, MAREK

1992 Die Fibeln vom Typ Almgren 43 als Zeugnisse für die Anwesenheit eingewanderter Viktovalen im mittleren Donauraum. Prähistorische Zeitschrift (Berlin) 67/1, 90-111.

1999 Kultúra przeworska w dorzeczu górnej Cisy. Zarys problematyki. The Przeworsk Culture in the Upper Tisza basin. Outline of problems. Prace i Materiały (Łodz) 41, 137-159.

2001 The Upper Tisza Basin in the Roman Period. Remarks on settlements and cultural changes. In: Tejral J. (Hrsg.): Das mitteleuropäische Barbaricum und die Krise des römischen Weltreiches im 3. Jahrhundert. Brno, 105-136. 
2014 The Przeworsk culture and the problem of dating of the beginnings of the Blažice-Bereg culture. Kultura przeworska a zagadnienie datowania początków kultury Blažice-Bereg. In: Komoróczy, B. (Hrsg.): Sociální diferenciace barbarských komunit ve světle nových hrobových, sídlištních a sběrových nálezů (Archeologie barbarů 2011). Soziale Differenzierung barbarischer Gemeinschaften im Lichte der neuen Grab-, Siedlungs- und Lesefunde (Archäologie der Barbaren 2011) Brno, 317-334.

2017 The problems connected with the identification and localisation of the Suebian tribe of Buri. Ephemeris Napocensis (Cluj-Napoca) 27, 187-196.

OTTOMÁNYI KATALIN

2012 Római vicus Budaörsön (Der römische vicus von Budaörs). Régészeti tanulmányok. Budapest.

PÁRDUCZ MiHÁLY

1957 Római császárkori lelet Miskolcon (Siedlung aus der römischen Kaiserzeit in Miskolc). A Herman Ottó Múzeum Évkönyve (Miskolc) 1, 45-59.

PÁRducz MiHÁLy-KoreK JózSEF

1958 Császárkori telep Ózdon. Archaeologiai Értesítő (Budapest) 85, 18-36.

PEŠKAR, IVAN

1972 Fibeln aus der römischen Kaiserzeit in Mähren. Praha.

PIETA, KAROL

1999 Anfänge der Völkerwanderungszeit in der Slowakei. (Fragestellungen der Zeitgenössischen Forschung). In: Tejral, J.-Pilet, C.-Kazanski, M. (eds): L'Occident romain et l'Europe centrale au début de l'époque des Grandes Migrations. Spisy AÚ-SAV ČR Brno, 171-190.

2010 Die keltische Besiedlung der Slowakei. Jüngere Latènezeit. ASM XII. Nitra.

PINTYE GÁbOR

2009 A Kárpát-medencei szarmata települések csontfésúi (Die Beinkämme der Sarmatensiedlungen im Karpatenbecken). Archaeologiai Értesítő (Budapest) 134, 165-196.

SALAMON ÁGNES

Császárkori településrészlet Beregből: Mol 49. lelőhely (Beregdaróc-Zsid). Gesta 9, 98-152.

1966 Észak-Magyarország császárkori történetének kutatása. AntTan 13, 84-87.

1970 Zalkod-Jakab domb. Kaiserzeitliche Siedlung. Antaeus Communicationes ex Instituto Archaeologico Academiae Scientiarum (Budapest) 1, 143-144, Taf. 31.

SALAMON ÁGNES-TÖRÖK GYULA

1960 Funde von Nordost-Ungarn aus der Römerzeit. Folia Archaeologica 12, Budapest 145-172.

SOÓS ESZTER

2011 Császárkori ipari (?) tevékenység nyomai a Hernád völgyében. The signs of Roman Age Industry in the Hernád-valley. Archeometriai Múhely 2011/4, 329-336.

2014 Garadna-Kastély zug. A római császárkori germán teleprészlet újraértékelése. Garadna-Kastély zug. Reassessment of a germanic settlement from the Roman Age. Communicationes Archaeologicae Hungariae (Budapest) 121-152.

2015 A Hernád-völgy településtörténete a Kr. u. 1-4/5. században. Doktori disszertáció ELTE BTK Történelemtudományi Doktori Iskola, Budapest.

2016 Settlement history of the Hernád Valley in the $1^{\text {st }}$ to $4 / 5^{\text {th }}$ centuries AD (Thesis abstract). Dissertationes Archaeologicae Ser. 3. No. 4, 449-466.

2017 Przeworsk település részlete a Zemplén lábánál. Adatok a Przeworsk-kvád kapcsolatokhoz. Settlement Remains of Przeworsk Culture in Zemplén Mountains (northern Hungary). New Data about PrzeworskQuad Relations. In: Merva Sz. (szerk.), Hadak útján XXII. A népvándorláskor fiatal kutatóinak XXII. konferenciája. Visegrád, 2012. október 2-4. (Assembly of Young Scholars on the Migration Period XXII Visegrád, October 2-4, 2012) Altum Castrum. A visegrádi Mátyás Király Múzeum füzetei 9. Visegrád, 17-56.

SOÓs, ESZTER-BÁRÁNY, ANNAMÁRIA-KÖHLER, KITTI-PUSZTAI, TAMÁS

2017 Settlement and graves from Hernádvécse (NE-Hungary) in the $5^{\text {th }}$ century AD: relation of living space and burial place in the Hun Period. Kr. u. 5. századi telep és temetkezések Hernádvécséról: adatok a lakóhely és a temetkezések kapcsolatához a hun korban. A Herman Ottó Múzeum Évkönyve 56, 49-98.

in press Bepecsételt díszítésú kerámia a magyarországi Przeworsk településeken: a „Bereg-kultúra” értelmezése. Communicationes Archaeologicae Hungariae (Budapest)

SOÓs, ESZTER-TANKÓ, KÁROLY

2018a Late Roman Period Quad settlement in Pásztó-Csontfalva. In: Borhy, L.-Dévai, K.-Tankó, K. (eds): Celto - Gallo - Roman Studies of the MTA-ELTE Research Group for Interdisciplinary Archaeology. Budapest, 281-301.

2018b An Attempt at Interpretation of the La Tène and Roman Period Settlement Finds from Szilvásvárad in Northeast-Hungary. In: Berecki, S.-Rustoiu, A.-Egri, M. (eds): Iron Age Connectivity in the Carpathian Basin. Proceedings of the International Colloquium from Târgu Mureş 13-15 October 2017. Cluj-Napoca, 77-90. 
SÓSKUTI KORNÉL-WILHELM GÁBOR

2014 Felgyő-Kettőshalmi dúlőben (20/77, Nr. 85. lelőhely) feltárt szarmata településrészlet római eredetû leletanyaga. A Móra Ferenc Múzeum Évkönyve (Szeged) Új folyam 1, 61-100.

STANCIU, IOAN

1995 Conrtibuții la cunoaşterea romane in bazinul Mijlociu şi inferior al Răului Someş. Ephemeris Napocensis

ŠVAŇA, KAMIL

(Cluj-Napoca) 15, 139-226.

2011 The influence of roman provincial pottery manufacture on the production of the suebic wheel-made Pottery. In: Kuzmová, K. (ed.): The Phenomena of cultural borders and border cultures across the passage of time (from the Bronze Age to Late Antiquity). Dedicated to the $375^{\text {th }}$ Anniversary of Universitas Tyrnaviensis. Trnava, 22-24 October 2010. Anodos. Studies of the Ancient World. Trnava, 10/2010, 283-294.

TANKÓ KÁROLY

2010 La Tène ceramic technology and typology of settlement assemblages in Northeast Hungary $\left(3^{\text {rd }}-2^{\text {nd }}\right.$ Century B.C). In: Bereczki S. (eds): Iron Age Communities in the Carpathian Basin. Proceedings of the international Colloquium from Târgu Mureş 9-11 Oktober 2009. Cluj-Napoca, 321-331.

TEJRAL, JAROSLAV

1992 Einige Bemerkungen zur Chronologie der spaten römischen Kaiserzeit in Mitteleuropa. In: Godłowski, K.-Madyda-Legutko, R. (Hrsg.): Probleme der Relativen und Absoluten Chronologie ab Laténe zeit bis zum Frühmittellter. Materialen des III. Symposium. Grundprobleme der Frühgeschichtliche Entwicklungen in nördliche MittelDonau Gebiet. Krakow, 227-248.

2008 Ke zvláštnostem sídlištního vývoje v době římské na území severně od středního Dunaje. Zu den besonderheiten der kaiserzeitlichen Siedlungsentwicklung nördlich des mitterlen Donauraumes. In: Droberjar, E.-Komoróczy, B.-Vachủtová, D. (eds): Barbarská Sídliště. Chronologické, ekonomické a historické aspekty jejich vývoje ve nových archeologických výzkumů (Archeologie barbarů) Brno, 67-98.

VADAY, ANDREA

1989 Die sarmatischen Denkmäler des Komitats Szolnok. Ein Beitrag zur Archäologie und Geschichte des sarmatischen Barbaricums. Antaeus Communicationes ex Instituto Archaeologico Academiae Scientiarum (Budapest) 17-18.

1996 Roman Period Barbarian Settlement at the Site of Gyoma 133. In: Vaday, A.-Bartosiewitz, L.-Berecz, K.-Choyke, A. M.-Medzihradszky, Zs.-Puszta, S.-Székely, B.-Vicze, M.-Vida, T.: Cultural and Landscape Changes in South-East Hungary II.: Prehistoric, Roman Period Barbarian and Late Avar Settlement at Gyoma 133 (Békés Country Microregion). Archaeolingua 5. Budapest, 51-307.

1998 Kereskedelem és gazdasági kapcsolatok a szarmaták és a rómaiak között. In: Havassy P. (szerk.): Jazigok, roxolánok, alánok. Szarmaták az Alföldön. Gyulai Katalógusok 6. Gyula, 117-143.

VADAY, ANDREA-Kulcsár, VALÉRIA (ВАДАИ, АНДРеA Х.-КуЛЬЧАР, ВАЛЕРИя)

1984 К вопросу о так называемых сарматских пряжках. Acta Archaeologica Academiae Scientiarum Hungaricae (Budapest) 36, 239-261.

VAKULENKO, LIANA

1998 One- piece fibulae with chord in high position and inverted foot (Almgren 158) and aspects of the chronology of the Roman Age sites in the Transkarpathian Ukraine. In: Kunow, J. (Hrsg.): 100 Jahre Fibelformen nach Oscar Almgren. Internationale Arbeitstagung 25.-28. Mai 1997 Kleinmachnow, Land Brandenburg. Forschungen zur Archaologie im Land Brandenburg 5, Wunsdorf, 241-247.

2008 The eastern Carpathians in the Late Roman Period. Acta Archaeologica Carpathica (Kraków) 42-43, 141-183.

VARSIK, VLADIMIR

1999 Ländliche Besiedlung im Hinterland des Kastells Gerulata. Siedlung der autochtonen Bevölkerung in Rusovce. Roman Frontier Studies XVII/1997. Zalău, 629-642.

2011 Germánske osídlenie na vŷchodnom predpolí Bratislavy. Sídliská z doby rímskej v Bratislave-Trnávke a v okolí. Archaeologica Slovaca Monographiae Tom. XVIII. Nitra.

VÉGH KATALIN

1964 Koracsászárkori település maradványa a miskolci Szabadság téren (Frühkaiserzeitliche Siedlungsreste auf dem Szabadság tér in Miskolc. The relic of a settlement from the late period of the empire [Miskolc]). A Herman Ottó Múzeum Évkönyve (Miskolc) 4, 45-62.

1975 Régészeti adatok Észak-Magyarország I-IV. századi történetéhez (Archäologische Beiträge zur Geschichte Nordostungarn im I-IV. Jh. u Z.). A Herman Ottó Múzeum Évkönyve (Miskolc) 13-14, 65-130.

1985 Császárkori telep Észak-Magyarországon (Kaiserzeitliche Siedlung in Nordungarn). Archaeologiai Értesítő (Budapest) 112, 92-108. 
1989 Császárkori telep Miskolc-Szirmán (Kaiserzeitliche Siedlung in Miskolc-Szirma). A Herman Ottó Múzeum Évkönyve (Miskolc) 27, 463-500.

1999 Császárkori telep Szirmabesenyőn (Eine Siedlung aus der Kaiserzeit in Szirmabesenyő). A Herman Ottó Múzeum Évkönyve (Miskolc) 37, 181-223.

VÖRÖS ISTVÁN-SOÓS ESZTER

2014 Észak-magyarországi császárkori települések archeozoológiai vizsgálata (Archaeozoological investigation of Imperial Age settlements from North-Hungary). Communicationes Archaeologicae Hungariae (Budapest) 153-168.

\section{NEW ADVANCES IN THE RESEARCH OF THE GERMANIC PRZEWORSK CULTURE OF THE ROMAN PERIOD IN HUNGARY}

\section{EsZTER SOÓs}

Discussed in this study are the new advances made in the research on the settlements of the Roman-period Przeworsk culture in Hungary.

With its core territory in Poland, the Przeworsk culture reached its greatest extent in the Carpathian Basin during the Marcomannic Wars and in the ensuing decades: its distribution stretched to the Dacian limes in the south-east, it had a well-defined boundary with the Sarmatian lands on the Hungarian Plain in the south, while the culture's western boundary with the Quadic territory remains uncertain. In contrast to the scattered sites with a few cremation burials whose majority can be dated between the later second and the earlier third century AD, life on the settlements extending densely along various watercourses can be traced up to the late Roman period, with some settlements remaining occupied up to the final third of the fourth century AD.

The settlements characterised by the sunken-floor, timber-framed buildings, storage pits, large pit complex- es filled with refuse and rectangular hearths of uncertain function typical for the Barbaricum were occupied by farming communities. These settlements generally form chains along watercourses. The finds from these settlements include hand-thrown, black polished fine wares for food consumption and festive occasions as well as coarse hand-thrown cooking vessels, alongside vessels turned on a fast wheel made in pottery workshops that appeared from the second half or close of the second century AD. Large storage jars served for storing various commodities.

On the testimony of the finds, the occupants of the Przeworsk settlements principally maintained trade and exchange relations with the province of Pannonia. The impact of the material culture of the neighbouring Sarmatian and Quadic lands is evidenced by certain formal traits and ornamental motifs of the pottery, rather than by imported articles.

A cikk a Creative Commons Attribution 4.0 International License (https://creativecommons.org/licenses/by/4.0) feltételei szerint publikált Open Access közlemény, melynek szellemében a cikk bármilyen médiumban szabadon felhasználható, megosztható és újraközölhető, feltéve, hogy az eredeti szerző és a közlés helye, illetve a CC License linkje és az esetlegesen végrehajtott módosítások feltüntetésre kerülnek. (SID_1) 
